\title{
Progress of Bio-Calcium Carbonate Waste Eggshell and Seashell Fillers in Polymer Composites: A Review
}

\author{
Stephen Owuamanam and Duncan Cree * \\ Department of Mechanical Engineering, University of Saskatchewan, 57 Campus Drive, Saskatoon, SK S7N 5A9, \\ Canada; stephen.owuamanam@usask.ca \\ * Correspondence: duncan.cree@usask.ca; Tel.: +1-306-966-3244
}

Received: 22 May 2020; Accepted: 7 June 2020; Published: 9 June 2020

check for updates

\begin{abstract}
Disposal of massive amounts of eggshells and seashells from processing industries is a challenge. In recent years, there has been a focus to reuse these waste resources in the production of new thermoplastic and thermoset polymer materials. This paper reviews eggshell and seashell production by country and provides a perspective on the quantity of bio-calcium carbonate that could be produced annually from these wastes. The achievements obtained from the addition of recycled bio-calcium carbonate fillers (uncoated/unmodified) in polymer composites with a focus on tensile strength, flexural strength and impact toughness are discussed. To improve compatibility between calcium carbonate (mineral and bio-based) fillers and polymers, studies on surface modifiers are reviewed. Knowledge gaps and future research and development thoughts are outlined. Developing novel and innovative composites for this waste material could bring additional revenue to egg and seafood processors and at the same time reduce any environmental impact.
\end{abstract}

Keywords: calcium carbonate; waste eggshells; waste seashells; polymer filler; surface modifiers; composites

\section{Introduction}

Low-cost fillers are added to polymers to reduce cost and improve their properties. One widely used inorganic filler is mineral limestone or calcium carbonate. An alternative to mined limestone are waste bio-materials such as chicken eggshells and seashells (marine mollusks, mussels, shellfish, oysters, scallops, and cockles) from the egg and seafood processing industries, respectively, which contain high calcium carbonate contents. They are abundant and are discarded by-products which can serve as potential substitutes for limestone derived from sedimentary rocks. A small portion of these bio-calcium carbonate wastes have found niche applications as animal feed supplements, remediation of acidic soils, and treatment of wastewaters [1-3]. However, the majority of waste chicken eggshells and seashells around the world are disposed of in landfills which tend to pose environmental problems [4]. Their decomposition produces ammonia, hydrogen sulfide and amines with significant odors [5-7]. In addition to a foul smell and attracting mice, rats, flies and insects, pathogens such as Escherichia coli (E. coli) [8] and Salmonella [8,9] are present in eggshell and seashell waste. In addition, untreated seashell waste can lead to leaching of heavy metals from the viscera [10]. In the US, eggshell waste has been placed 15th on the Environmental Protection Agency (EPA) list of food industries creating pollution problems [11], while the European Commission regulations consider industrial eggshell byproducts as hazardous waste [12]. In recent developments, one method to mitigate disposal problems is to find novel applications by reusing and recycling of bio-based calcium carbonate as fillers for polymer matrix composite materials.

The egg processing industry consists of large-scale hatcheries and breaker plants where the latter yields liquid, powdered and frozen eggs for wholesale food producers and bakeries, while 
seashell waste are derived from various shellfish generated from the seafood processing industry. As the global population increases, the production and consumption of eggshell and seashell products are projected to increase [13]. Greater quantities of waste eggshells (and seashells) suggest higher landfilling costs borne solely by the processors. For example, in the US it can cost one breaker plant about US $\$ 100,000$ per year to dispose of eggshells into landfills [14], while in the United Kingdom, Just Egg (Chilled foods) Ltd. spends about $£ 50,000$ ( US\$65,000) a year to dispose of eggshells [15]. In Europe it can costs small- to medium-sized egg processing companies about $€ 100,000$ ( US\$112,000) per year for disposal [12]. Similarly, seashell producers also consider shellfish a nuisance waste product as it costs them financial losses for proper disposal [16]. The consensus from companies is that they would be satisfied if someone was to take the eggshell waste off their hands for free as this would decrease their landfill tipping fees.

The desire to recycle waste eggshells is in its infancy. In recent years there has been an upswing with several small-scale start-up companies that have separated the membrane from waste eggshells at an industrial scale. For instance, Eggnovo (Spain) utilized calcium carbonate from eggshells for use in food, food supplements, cosmetics and pharmaceutical sectors [17]. American Dehydrated Foods (USA) in conjunction with Georgia Institute of Technology researchers has been developing a separation facility to recover calcium carbonate from eggshells for possible use in plastics in an effort to reduce petroleum-based products [15]. Similarly, Just Egg (United Kingdom) along with Leicester University have designed a pilot plant to produce eggshell powders for possible use as fillers to reinforce plastics [18]. These demonstration plants could be models for recuperating eggshells in other countries as well as adapting them to recover seashells. In a short time, plastic industries may be interested in using eggshell powders as filler materials but would be dependent on price since calcium carbonate from rocks is relatively low cost [18].

To advance the understanding in the field of bio-calcium carbonate fillers combined with polymers, a need to review past studies on the progress made was required in order for users to make well-informed decisions. This work attempts to provide a framework on the important studies in the area of mechanical properties (tensile strength, flexural strength and impact toughness) and outlines the knowledge gaps of calcium carbonate-based particulate-filled thermoplastics and thermoset polymer composites. A review on the use of waste-based calcium carbonate as a sustainable filler has not been published in the literature and will be meaningful for the polymer composite industry.

\section{Composition and Sources of Eggshells and Seashells}

In nature, calcium carbonate exists as a mineral in sedimentary rocks such as limestone and chalk and in metamorphic marble rocks [19] where they are often extracted via quarry or underground mining. Three crystal polymorphs of calcium carbonate exist in nature in decreasing order of stability: calcite, aragonite and vaterite [20]. Limestone, chalk and marble are primarily composed of calcite. The density of natural limestone ranges from $2.50-2.71 \mathrm{~g} / \mathrm{cm}^{3}$ [21,22]. Its major applications in engineering materials have been for fillers in polymer composites [23] as well as raw materials for cement and mortar production [21]. Apart from mineral limestone, there are an abundance of industrial waste materials containing high calcium carbonate contents in the form of chicken eggshells and various seashells.

\subsection{Eggshell Structure and Composition}

An eggshell is the hard outer layer of a chicken egg and can be brown- or white-coloured [24]. A chicken egg consists of $60 \%$ albumen (the liquid white colored substance), $30 \%$ yolk (the liquid yellow colored substance) and 10-11\% shell (the solid eggshell and organic membrane) [25]. The total weight of an average egg was reported to be between 60.0-60.2 $\mathrm{g}[26,27]$, while the empty shell weight ranges between 6.6-7.3 g [25,26]. The eggshell structure shown in Figure 1 is composed of three main layers; an outermost layer surrounding the eggshell called the cuticle, the layer beneath is referred to as the testa ("the shell") and the innermost layer termed the mammillary layer [28]. Under the 
mammillary layer are two shell membranes termed outer-shell membrane and inner-shell membrane. The cuticle (dried mucus) layer is a thin film of about $10 \mu \mathrm{m}$ which protects the embryo from bacterial infection and moisture loss [28]. In the literature, the term testa has also been referred to as the palisade layer as both contain calcite crystals. The palisade (spongy) layer is arranged in columns and is the thickest layer (about $100 \mu \mathrm{m}$ ) of the eggshell. It provides calcium and aids in coloration to the growing egg [28]. In-between the palisade columns are small pores. It is estimated that the shell contains 7000 to 17,000 unevenly distributed circular pore openings which function to allow gas exchange of oxygen from the atmosphere and carbon dioxide release produced by the baby chicken $[29,30]$. Studies compared scanning electron microscope images at the same magnification of eggshell powders with mineral limestone powders and observed the presence of pores in eggshells and the absence in limestone [31,32]. This suggests that the pores in eggshells are larger than those in limestone. The palisade layer is composed of about $95 \%$ calcium carbonate, $3.3 \%$ organic proteins and $1.6 \%$ moisture [33]. The mammillary layer consists of cones/knobs made from organic protein and are the seeding sites on which the testa/palisade columns grow [34]. The outer-shell membrane (visible to the naked eye and which cannot manually peel-off easily) is thicker than the inner-shell membrane and together have a thickness of about $100 \mu \mathrm{m}$. Both membranes are assemblies of a network of protein fibers [35]. To gain a better understanding of the layered structures of a chicken eggshell, researchers have heated eggshells at various elevated temperatures and viewed them under the scanning electron microscope [36,37].

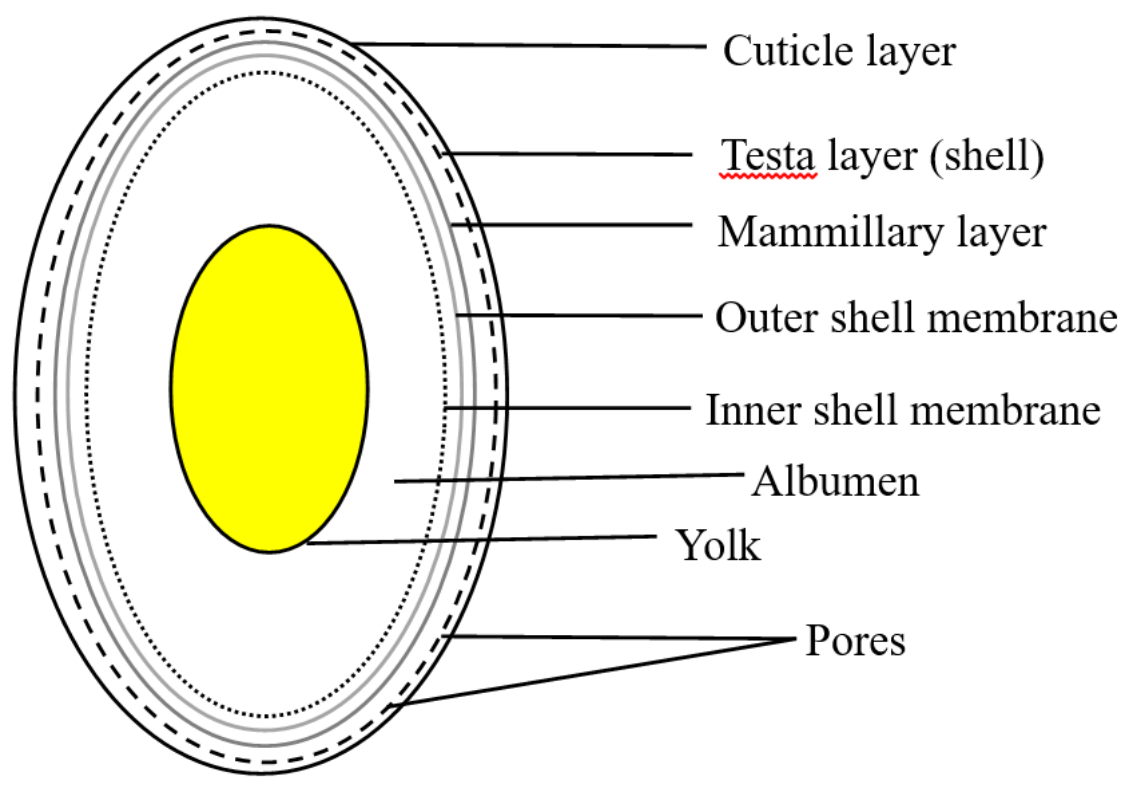

Figure 1. Structure of an eggshell.

The chemical composition of eggshells are calcium carbonate in the form of calcite ranging from 94-97\% [28,38,39] and 3-4.5\% organic matter [26,40,41]. In addition, minor traces of other elements have been detected such as; $\mathrm{MgO}(0.83 \%), \mathrm{SO}_{3}(0.66 \%), \mathrm{P}_{2} \mathrm{O}_{5}(0.43 \%), \mathrm{Al}_{2} \mathrm{O}_{3}(0.15 \%), \mathrm{K}_{2} \mathrm{O}(0.08 \%), \mathrm{SiO}_{2}$ $(0.07 \%), \mathrm{Cl}_{2} \mathrm{O}_{3}(0.06 \%)$ and $\mathrm{SrO}(0.04 \%)$ [42]. There are slight variations in composition from study to study which may be attributed to the type of chicken feed and possible impurities generated by organic proteins and membranes. The color of the shell does not dictate the amount of calcium carbonate. For example, brown eggshells were reported to contain $96-97 \%$ calcium carbonate and $3-4 \%$ organic membrane [38,43], while white eggshells were found to have $94 \%$ calcium carbonate content with $6 \%$ organic membrane [27,44]. Based on these findings, the calcium carbonate contents in both brown and white eggshells were considered equivalent [41]. The density of the eggshell has been quantified from various studies to be; $2.50 \mathrm{~g} / \mathrm{cm}^{3}$ [41], $2.53 \mathrm{~g} / \mathrm{cm}^{3}$ [28], $2.59 \mathrm{~g} / \mathrm{cm}^{3}$ [38] and $2.62 \mathrm{~g} / \mathrm{cm}^{3}$ [39]. The eggshell 
density is slightly less than the mineral limestone possibly due to the porous nature of eggshells. The outer-shell membrane density has been reported to be smaller with a value of $1.36 \mathrm{~g} / \mathrm{cm}^{3}$ [28].

\subsection{Sources of Eggshell Waste}

Sufficient quantities of waste eggshells would be required for industrializing a recovery process. Households and restaurants would not be a viable route to obtain waste eggshells, rather they would be obtained from egg processors 'breaker plants'. The first known egg breaker plant was invented in 1928 in the United States before World War II [45]. In this process, the liquid egg is mechanically separated from the shells, which lead to eggshells being obtained in large quantities. For instance, a modern breaker plant can process 188,000 eggs per hour. Eggs are classified into sizes and standards where sub-standard eggs not suitable for the general market are sent to breaker plants while quality medium, large and extra-large eggs are sent to market [46].

The top 10 egg-producing countries are presented in Figure 2 and Table 1. Roughly $30 \%$ of eggs are sent to breaker plants for processing into liquids [31]. The amount of calcium carbonate $\left(\mathrm{CaCO}_{3}\right)$ from eggshell waste that could be recuperated are outlined in Table 1.

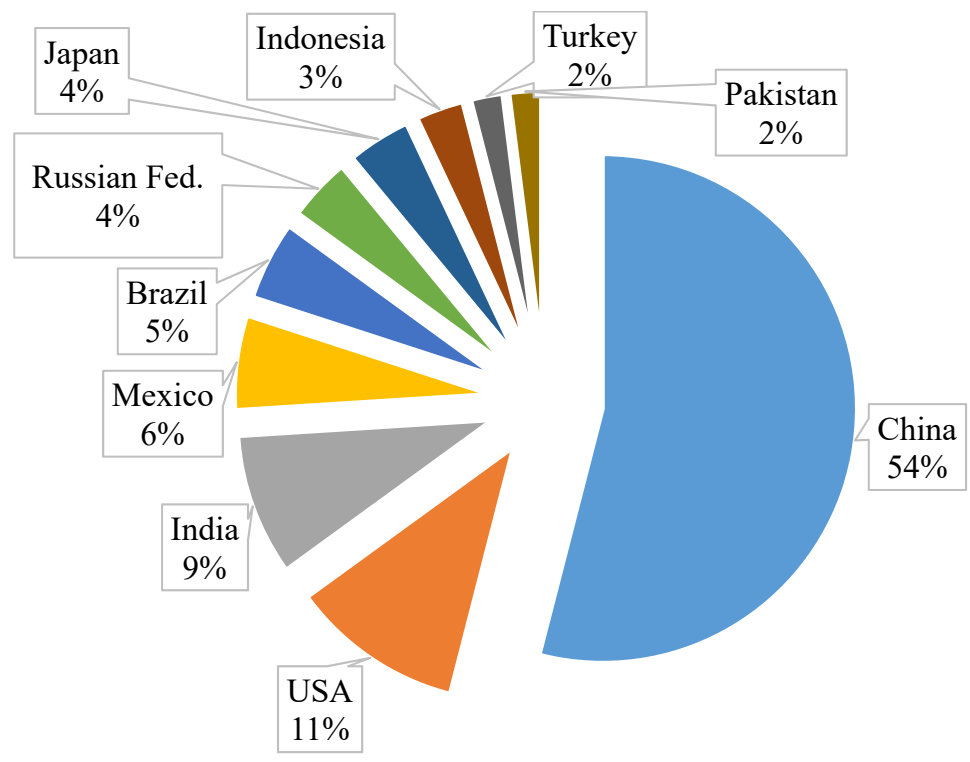

Figure 2. Global pie chart of eggs produced annually in 2017.

Table 1. Annual egg production by the top 10 countries in $2017\left({ }^{*}\right.$ values multiplied by 1000$)$.

\begin{tabular}{cccc}
\hline Country & $\begin{array}{c}* \text { Number of Eggs Produced } \\
\text { Annually in (2017) }[47]\end{array}$ & $\begin{array}{c}* \text { 30\% of Eggs Are Sent to Breaker } \\
\text { Plants (Quantity of Eggs) }\end{array}$ & $\begin{array}{c}\text { Amount of CaCO } \\
\text { Recuperated (kg) }\end{array}$ \\
\hline China & $536,818,007$ & $161,045,402$ & $1,062,899,654$ \\
USA & $106,688,700$ & $32,006,610$ & $211,243,626$ \\
India & $88,137,000$ & $26,441,100$ & $174,511,260$ \\
Mexico & $55,418,430$ & $16,625,529$ & $109,728,491$ \\
Brazil & $43,352,883$ & $15,283,022$ & $100,867,948$ \\
Russian Fed. & $44,351,037$ & $13,305,311$ & $87,815,053$ \\
Japan & $43,352,883$ & $13,005,865$ & $85,838,708$ \\
Indonesia & $33,940,000$ & $10,182,000$ & $67,201,200$ \\
Turkey & $19,281,196$ & $5,784,359$ & $38,176,768$ \\
Pakistan & $17,083,000$ & $5,124,900$ & $33,824,340$ \\
\hline
\end{tabular}

The values in kilograms $(\mathrm{kg})$ of recuperated $\mathrm{CaCO}_{3}$ are based on an empty eggshell weight of approximately $6.6 \mathrm{~g}$. As an example, China's annual production in 2017 was 536,818,007,000 eggs. Of this amount, $30 \%$ equates to $161,045,402,000$ eggs. Therefore, approximately 1,062,899,654 $\mathrm{kg}$ could be recovered. Putting this into perspective, about 35,429,988 bags of $\mathrm{CaCO}_{3}$ powder, each of $30 \mathrm{~kg}$, 
could be produced from eggshell waste annually. It is important to note, the aim of this review is not to eliminate limestone derived from rocks, but it is to make use of a waste material.

\subsection{Marine Seashell Composition}

A seashell can be defined as the hard outer layer from the body of an animal that lives in the sea such as marine mollusks; mussels, oysters, scallops, clams, snails and cockles. Sea animals are food proteins extensively consumed by humans and their shells are widely disposed to landfills [48]. Studies determined the chemical composition of various seashells to be calcium carbonate in the range of $92-99 \%$ [48-50] with about 5\% organic matter [51]. The majority of seashell types studied reported calcium oxide $(\mathrm{CaO})$ contents rather than $\mathrm{CaCO}_{3}$ contents [52-54]. This suggests the removal of organic material from seashells may be difficult and heating to elevated temperatures results in a purified form. For instance, heated oyster shells have been reported to contain $\mathrm{CaO}(51.06 \%)$, with fractions of $\mathrm{SiO}_{2}(2 \%), \mathrm{Al}_{2} \mathrm{O}_{3}(0.50 \%), \mathrm{Fe}_{2} \mathrm{O}_{3}(0.20 \%), \mathrm{MgO}(0.51 \%), \mathrm{SO}_{3}(0.60 \%), \mathrm{K}_{2} \mathrm{O}(0.06 \%), \mathrm{Na}_{2} \mathrm{O}(0.58 \%), \mathrm{TiO}_{2}$ $(0.02 \%), \mathrm{Mn}_{2} \mathrm{O}_{3}(0.02 \%), \mathrm{P}_{2} \mathrm{O}_{5}(0.18 \%)$ and $\mathrm{SrO}(0.09 \%)$ as a well as a $44.16 \%$ loss of $\mathrm{CO}_{2}$ and organic materials [55]. To identify the amount of calcium carbonate in seashells from $\mathrm{CaO}$ contents, estimates were calculated using Equation (1) and results presented in Table 2. This is helpful to compare literature that has only reported calcium carbonate contents.

$$
\% \mathrm{CaCO}_{3}=\frac{\mathrm{CaCO}_{3} \mathrm{MW}}{\mathrm{CaO} \mathrm{MW}} * \mathrm{CaO} \text { WR or content }(\%)
$$

where, $\mathrm{CaCO}_{3} \mathrm{MW}, \mathrm{CaO} \mathrm{MW}$ and $\mathrm{CaO}$ WR are calcium carbonate molecular weights (e.g. 100), calcium oxide molecular weight (e.g. 56), and calcium oxide weight ratio or content in\%, respectively. The calculated results are in the range of $91-97 \% \mathrm{CaCO}_{3}$. The density of dried mussel shells have been stated to be $1.33 \mathrm{~g} / \mathrm{cm}^{3}$ [49], while oyster shells were $1.15-2.62 \mathrm{~g} / \mathrm{cm}^{3}[7,56]$.

Table 2. $\mathrm{CaCO}_{3}$ composition of seashells ( ${ }^{*}$ calculated based on Equation (1)).

\begin{tabular}{ccccc}
\hline Seashell Type & $\mathrm{CaCO}_{3}$ Content (\%) & $\mathbf{C a O}$ Content (\%) & Density $\left(\mathbf{g} / \mathbf{c m}^{\mathbf{3}}\right)$ & Ref. \\
\hline \multirow{4}{*}{ Cockle shell } & 98.99 & - & - & {$[57]$} \\
& 97.13 & - & - & {$[53]$} \\
& $92.70^{*}$ & 51.91 & - & {$[54]$} \\
Mussel shell & $92.07^{*}$ & 51.56 & - & {$[58]$} \\
\hline $95.89^{*}$ & $95.60^{*}$ & 53.70 & - & {$[52]$} \\
& 95.25 & 53.38 & - & {$[53]$} \\
& 95.00 & - & - & {$[59]$} \\
Oyster shell & $97.40^{*}$ & - & 1.33 & {$[49]$} \\
\hline & $96.98^{*}$ & 54.54 & - & {$[60]$} \\
& $96.80^{*}$ & 54.31 & - & {$[61]$} \\
& $96.10^{*}$ & 53.59 & - & {$[53]$} \\
& 95.99 & 53.81 & 1.15 & {$[62]$} \\
& $94.54 *$ & - & - & {$[7]$} \\
Mollusks & 92.78 & 52.94 & 2.62 & {$[52]$} \\
Shellfish & $91.18^{*}$ & - & 2.39 & {$[56]$} \\
\hline Scallop & 94.10 & 51.06 & - & {$[55]$} \\
\hline
\end{tabular}

\subsection{Sources of Seashell Waste}

Similar to waste eggshells, the number of seashells from homes and restaurants would not be adequate for an industrial calcium carbonate extraction process. Instead, large amounts of seashell 
waste are generated from canning industries. The top 10 seafood-producing countries are presented in Table 3. The literature source did not differentiate between the types of seashells by country, therefore a general overview is provided. For every oyster shell dozen consumed, about 370-700 g of empty shells are recovered $[50,64]$. This implies that for one oyster protein consumed, the shell weight recovered is in the range of 30.83-58.33 g. The dry weight of one mussel shell was found to be approximately 0.01-40 g [65], one mollusk shell to be 0.317-2.08 g [66], one empty cockle shell to be $1 \mathrm{~g}$ [67] and a sea scallop to be $0.4 \mathrm{~g}$ [68]. Based on the above studies, the dry shell weight of oysters, mussels, mollusks, cockles and scallops ranges from $0.01 \mathrm{~g}$ to $58.33 \mathrm{~g}$ or approximately $52-80 \%$ of the whole animal. Table 4 shows the annual mollusk consumption for the top three countries in 2013 [47]. For instance, China consumed 12,537,301 tonnes of mollusk. The amount of $\mathrm{CaCO}_{3}$ that could be recovered in $\mathrm{kg}$ are based on one mollusk shell having a dry weight in the range of 0.317-2.08 $\mathrm{g}$ [66]. Therefore, in China about 3,974,324-26,077,587 kg of $\mathrm{CaCO}_{3}$ could be recuperated from mollusk waste annually.

Table 3. Annual seafood production by the top 10 countries in 2016.

\begin{tabular}{ccc}
\hline Country [69] & Seafood Production in 2016 (Tonnes) & Seafood Production in 2016 (kg) \\
\hline China & $17,564,280$ & $17,564,280,000$ \\
Indonesia & $6,542,258$ & $6,542,258,000$ \\
India & $5,061,756$ & $5,061,756,000$ \\
USA & $4,919,741$ & $4,919,741,000$ \\
Russian Fed. & $4,759,331$ & $4,759,331,000$ \\
Peru & $3,796,978$ & $3,796,978,000$ \\
Japan & $3,195,558$ & $3,195,558,000$ \\
Vietnam & $2,785,940$ & $2,785,940,000$ \\
Myanmar & $2,072,390$ & $2,072,390,000$ \\
Norway & $2,033,953$ & $2,033,953,000$ \\
\hline
\end{tabular}

Table 4. Annual mollusk consumption by the top three countries in 2013.

\begin{tabular}{|c|c|c|c|c|}
\hline Seashell Type & $\begin{array}{l}\text { Dry Weight of } \\
\text { Shell (g) }\end{array}$ & $\begin{array}{c}\text { Consumption by Top } \\
\text { Three Countries }\end{array}$ & $\begin{array}{c}\text { Consumed in } 2013 \\
\text { (Tonnes) [47] }\end{array}$ & $\begin{array}{c}\text { Recuperated } \\
\mathrm{CaCO}_{3}(\mathrm{~kg})\end{array}$ \\
\hline Mollusk & $0.317-2.08[66]$ & China & $12,537,301$ & $3,974,324-26,077,587$ \\
\hline- & - & USA & $1,057,882$ & $335,349-2,200,395$ \\
\hline- & - & Japan & 819,416 & $259,755-1,704,386$ \\
\hline
\end{tabular}

\section{Bio-Calcium Carbonate Fillers in Polymer Composites}

Several lab-scale manufacturing processes and polymer matrices have been utilized for the fabrication of composites containing bio-calcium carbonate particulate fillers (uncoated/unmodified). Thermoplastic polymers require high processing temperatures to melt polymers while thermoset composites are cured at room temperature and further post-cured at an elevated temperature. To compare numerical results from research papers where only the graphs were available, data points were extracted directly from published article figures with the open source Web Plot Digitizer, version 4.1 [70].

\subsection{Thermoplastic Eggshell Fillers}

The effect of waste eggshell fillers on the mechanical properties of thermoplastic polymers have been assessed by several studies and are summarized in Table 5. In one study, the tensile Young's modulus (tensile strength not reported) of eggshells $(<38 \mu \mathrm{m})$ in a polypropylene (PP) matrix were determined. The eggshells were dried, mechanically triturated into powder, blended using a mixer and hot pressed into specimens. Only one filler loading of $40 w / w$ (or wt.\%) was studied which presented an increase in Young's modulus of approximately 136\% compared to the pure PP resin. The improvement was credited to a good eggshell/PP interface [71]. 
Table 5. Summary of thermoplastic polymers containing eggshell filler.

\begin{tabular}{|c|c|c|c|c|c|c|c|c|c|c|}
\hline PM & PT & $\mathrm{PZ}(\mu \mathrm{m})$ & FL & FT & TS (MPa) & TE (Gpa) & FS (Mpa) & FE (Gpa) & IT & Ref \\
\hline \multirow{2}{*}{ PP } & \multirow{2}{*}{ HP } & \multirow{2}{*}{$<38$} & 0 & \multirow{2}{*}{ None } & - & 1.1 & - & - & - & \multirow{2}{*}{ [71] } \\
\hline & & & 40 & & - & 2.6 & - & - & - & \\
\hline \multirow{5}{*}{ PP } & \multirow{5}{*}{$\mathrm{IM}$} & \multirow{5}{*}{$<149$} & & \multirow{5}{*}{ None } & & & & & $\mathrm{C}$ & \multirow{5}{*}{72} \\
\hline & & & 0 & & 33 & - & 25 & 1.0 & 2.1 & \\
\hline & & & 1 & & 33 & - & 26 & 1.1 & 2.9 & \\
\hline & & & 3 & & 33 & - & 26 & 1.1 & 3.1 & \\
\hline & & & 5 & & 32 & - & 26 & 1.1 & 3.1 & \\
\hline \multirow{6}{*}{ PP } & \multirow{6}{*}{$\mathrm{IM}$} & \multirow{6}{*}{$14-157$} & & \multirow{6}{*}{ None } & & & & & I & \multirow{6}{*}{ [73] } \\
\hline & & & 0 & & 27 & 0.50 & - & - & 58 & \\
\hline & & & 10 & & 26 & 0.62 & - & - & 25 & \\
\hline & & & 20 & & 24 & 0.87 & - & - & 35 & \\
\hline & & & 30 & & 22 & 1.8 & - & - & 40 & \\
\hline & & & 40 & & 17 & 1.6 & - & - & 28 & \\
\hline \multirow{6}{*}{ PP } & \multirow{6}{*}{$\mathrm{IM}$} & \multirow{6}{*}{3} & & \multirow{6}{*}{$\mathrm{NaOH}$} & & & & & I & \multirow{6}{*}{ [74] } \\
\hline & & & 0 & & 35 & 0.42 & - & 1.3 & 21.5 & \\
\hline & & & 5 & & 31 & 0.43 & - & 1.3 & 21.6 & \\
\hline & & & 10 & & 31 & 0.44 & - & 1.4 & 20.9 & \\
\hline & & & 20 & & 30 & 0.45 & - & 1.4 & 21.4 & \\
\hline & & & 30 & & 28 & 0.51 & - & 1.8 & 22.0 & \\
\hline \multirow{3}{*}{$\mathrm{PP}$} & \multirow{3}{*}{$\mathrm{CM}$} & \multirow{3}{*}{$100-350$} & 促 & \multirow{3}{*}{$\mathrm{NaOH}$} & & & & & I & \\
\hline & & & 0 & & 23 & 1.3 & 27 & 0.76 & 55 & [75] \\
\hline & & & 30 & & 20 & 1.6 & 28 & 0.99 & 81 & \\
\hline & & & 0 & & 13 & 0.82 & - & - & - & \\
\hline & & & 1 & & 13 & 0.97 & - & - & - & \\
\hline PPC & FC & $<40$ & 2 & None & 14 & 1.0 & - & - & - & [76] \\
\hline & & & 3 & & 18 & 1.2 & - & - & - & \\
\hline & & & 4 & & 23 & 1.4 & - & - & - & \\
\hline & & & 5 & & 14 & 0.98 & - & - & - & \\
\hline & & & 0 & & 19 & 0.09 & - & - & - & \\
\hline & & & 7.5 & & $24 / 23$ & $0.08 / 0.09$ & - & - & - & \\
\hline PVC & $\mathrm{HP}$ & $0.2 / 7$ & 15 & None & $22 / 20$ & $0.35 / 0.34$ & - & - & - & [77] \\
\hline & & & 22.5 & & $23 / 16$ & $0.50 / 0.40$ & - & - & - & \\
\hline & & & 30 & & $19 / 15$ & $0.58 / 0.40$ & - & - & - & \\
\hline & & & 0 & & 14 & 0.15 & - & - & - & \\
\hline & & & 5 & & 12 & 0.19 & - & - & - & \\
\hline LDPE & $\mathrm{HP}$ & 63 & 10 & $\mathrm{NaOH}$ & 11 & 0.23 & - & - & - & [78] \\
\hline & & & 15 & & 10 & 0.28 & - & - & - & \\
\hline & & & 20 & & 7 & 0.31 & - & - & - & \\
\hline & & & 25 & & 7 & 0.36 & - & - & - & \\
\hline
\end{tabular}

Polymer material (PM) where Polypropylene (PP); Polypropylene carbonate (PPC); Polyvinyl chloride (PVC); Low density polyethylene (LDPE); High density polyethylene (HDPE); Polystyrene (PS); Polylactic acid (PLA); Processing technique (PT) where Hot press (HP); Injection molding (IM); Compression molding (CM); Film casting (FC), Filler size (FZ); Filler loading (wt.\%) (FL); Filler treatment (FT); Tensile strength (TS); Young's modulus (TE); Flexural strength (FS); Flexural modulus (FE); Impact test (IT) where Charpy (C) or Izod (I).

In a related study, the effect of eggshells $(<149 \mu \mathrm{m})$ on the tensile, flexural and Charpy impact properties of PP were evaluated. The eggshells were dried and sieved (crushing method not reported). $\mathrm{PP} /$ eggshell composites with filler loadings of 1,3 , and $5 \mathrm{wt} . \%$ were initially homogenized in a mixer, pelletized and manufactured via injection molding. The filler additions did not affect the tensile properties (Young's modulus not reported). For instance, the tensile strengths did not significantly change with filler content. At $5 \mathrm{wt} . \%$, the tensile strength reduced by only $3 \%$. Similarly, the change in 
flexural strength and flexural modulus were not remarkable such that at $5 \mathrm{wt} . \%$, the greatest changes were $4 \%$ and $10 \%$, respectively. However, improvements were observed with Charpy impact toughness of $38 \%, 48 \%$, and $48 \%$, respectively. The authors suggested the drop in mechanical properties were due to poor compatibility of the hydrophobic PP with hydrophilic eggshell fillers [72]. Similarly, the effect of eggshell powders $(14-157 \mu \mathrm{m})$ on the mechanical properties of PP were determined. PP/eggshell composites contained 10, 20, 30 and $40 \mathrm{wt} . \%$ loadings. The eggshells were washed in warm water, dried and ball milled into powder. The materials were mixed with a twin screw extruder and further made into plates using a hot press. The tests presented a drop in the tensile strength and an increase in Young's modulus with filler loading. Pure PP presented a tensile strength of $27 \mathrm{MPa}$ but decreased by approximately 37\% at $40 \mathrm{wt} . \%$. The best tensile strength reduced by $4 \%$ with $10 \mathrm{wt}$. $\%$ filler. The Young's modulus improved by $220 \%$ at a $40 \mathrm{wt} . \%$ loading. The Izod impact results decreased for all loadings, but at $30 \mathrm{wt} . \%$ showed the highest value with a 31\% reduction in toughness compared to the pure PP. The authors proposed the decrease in tensile strengths were due to poor adhesion of the filler-matrix and agglomeration of eggshell particles while the increase in Young's modulus was due to the inclusion of rigid and stiff particles into the polymer. The impact toughness reduction was attributed to a composite containing a lower volume of polymer material [73]. In a related study, the effect of adding 5, 10, 20 and $30 \mathrm{wt}$ \% eggshell and mineral calcium carbonate $(3 \mu \mathrm{m})$ fillers to a PP matrix was analyzed. The eggshells were washed, dried, ball-milled, blended using a twin screw extruder and further injection molded into mechanical test specimens. The PP/eggshell composite tensile strengths decreased by 11-20\% with increase in filler loading while Young's modulus increased by $2-21 \%$ compared to pure PP. Similarly, the PP/mineral calcium carbonate composites reduced in tensile strength by 6-14\% but improved in Young's modulus by 2-25\%. In general, the mineral calcium carbonate composites had 3-7\% and 1-5\% higher tensile strengths and Young's modulus, respectively compared to the eggshell composites. The authors suggested the decrease in tensile strength for the eggshell composites was due to agglomeration of fillers in the matrix, while the improvement of modulus was due to the presence of the fillers. The flexural modulus (flexural strength not reported) increased by $0-38 \%$ with eggshell loading, while the Izod impact toughness augmented by $2 \%$ at $30 \mathrm{wt} . \%$ eggshell loading. The authors suggested that the increase in flexural modulus was due to the strong bonding between the matrix and filler [74]. In another work, eggshells were heated at $500{ }^{\circ} \mathrm{C}$ for $2 \mathrm{~h}$, mechanically ground and sieved to a particle size distribution of 100-350 $\mu \mathrm{m}$. The PP and eggshell powders (30 wt.\%) were compounded in a twin screw extruder, pelletized and fed into an extrusion/compression molding process to produce the various specimen shapes. The tensile strength decreased by 13\%, while the Young's modulus, flexural strength, flexural modulus and Izod impact toughness increased by $23 \%, 4 \%, 30 \%$ and $47 \%$, respectively. The authors advocated that the relatively large particle size of the filler material used served as stress concentrators which could have been responsible for the reduction in the tensile strength. In addition, the improvement in flexural properties may have been due to enhanced adhesion between the filler and the matrix [75].

Eggshells $(<40 \mu \mathrm{m})$ have also been added to a polypropylene carbonate (PPC) polymer. The eggshells were washed, dried and made into powder using a kitchen grinder-mixer. The PPC was dissolved in chloroform and the eggshell powder was added in filler contents of 1, 2, 3, 4, and 5 wt.\%. The PPC/eggshell composites were fabricated using a film-casting method. The results presented an improvement in both tensile strength and Young's modulus for all composites where the optimal loading was determined to be $4 \mathrm{wt}$.\%. For instance, the tensile strengths were reported to have increased by approximately $0 \%, 8 \%, 38 \%, 77 \%$ and $8 \%$, while the Young's modulus increased by $18 \%, 22 \%, 47 \%, 70 \%$ and $19 \%$ for $1,2,3,4$, and $5 \mathrm{wt} . \%$ loadings, respectively. A better dispersion and interaction between the matrix and the fine eggshell particles benefited the composites. The apparent decrease at $5 \mathrm{wt}$ \% loading may have been due to agglomeration of filler particles with increased filler concentrations [76].

The effect of eggshell particle sizes of $0.2 \mu \mathrm{m}$ and $7 \mu \mathrm{m}$ in amounts of 10, 20,30 and 40 phr on the mechanical properties of polyvinyl chloride (PVC) were studied. In order for the filler loading 
data in Tables 5-8 to be consistent, a personal communication with the corresponding author showed the conversion to wt. $\%$ used was: wt. $\%=($ phr of component/(total phr of the components $) * 100$. Therefore 10, 20, 30 and $40 \mathrm{phr}$ corresponds to 7.5, 15, 22.5 and $30 \mathrm{wt}$ \%, respectively. The eggshells were washed, dried and made into smaller pieces using a blender and further ground with a Retsch grinder. The ingredients were blended using a Rheo-Mix mixer and molded using a hot press. The tensile strength was optimal for $7.5 \mathrm{wt}$ \% fillers of $0.2 \mu \mathrm{m}$ and $0.7 \mu \mathrm{m}$ where it improved by $26 \%$ and $21 \%$, respectively, while at a maximum loading of $30 \mathrm{wt} . \%$, the Young's modulus increased by approximately $544 \%$ and $344 \%$, respectively, compared to pure PVC. Better composite tensile strengths were reported for $0.2 \mu \mathrm{m}$ fillers over $7 \mu \mathrm{m}$ particles. The $7 \mu \mathrm{m}$ particle size fillers had lower surface areas for interaction with the matrix which led to increased particle agglomeration through hydrogen bonding resulting in a higher dispersive resistance. The authors also proposed that the improved Young's modulus with $0.2 \mu \mathrm{m}$ fillers was a result of lower particle agglomeration [77].

Eggshell fillers have also been added to low-density polyethylene (LDPE) and high density polyethylene (HDPE). For instance, eggshell powders $(63 \mu \mathrm{m})$ were added to LDPE using filler contents of 5, 10, 15, 20 and $25 \mathrm{wt}$.\%. The eggshells were initially washed, dried and ground into powder using a blender. The powders were then treated with $10 \% \mathrm{NaOH}$ to remove additional organic membrane. LDPE/eggshell composites were mixed via a Z-blade mixer and further molded in a hot press. At all loadings, the tensile strengths decreased by approximately $14 \%, 21 \%, 29 \%, 50 \%$, and $50 \%$ and the Young's modulus increased by about 27\%, 53\%, 87\%, 107\% and 140\%, respectively. The authors suggested that the decrease in tensile strengths were due to poor adhesion between the filler and matrix as well as agglomeration of the filler materials while the increase in Young's modulus was attributed to the calcium carbonate eggshells exhibiting higher stiffness than the pure LDPE [78]. In another study, 20 wt.\% eggshells $(25 \mu \mathrm{m})$ were combined with HDPE. The eggshells were washed, dried and ground using an ultra-centrifugal mill. A twin screw co-rotating extruder was used to blend the components and further made into pellets for use in an injection-molding machine. At this loading level the Young's modulus, flexural strength, and flexural modulus increased by approximately $8 \%, 2 \%$, and $3 \%$, respectively, while the tensile strength and Charpy impact toughness decreased by $15 \%$ and $42 \%$, respectively. The authors suggested that there were no significant differences in the increase in flexural strength and flexural modulus compared to the pure matrix. Furthermore, the decrease in tensile strength was attributed to poor adhesion of filler-matrix and agglomeration of filler particles [42]. In a recent investigation $7 \mu \mathrm{m}$ eggshell powder were blended in an HDPE matrix in amounts of 10, 20, 30 and 40 phr which corresponded to 7.5, 15, 22.5 and $30 \mathrm{wt}$ \%, respectively. The waste eggshells were first washed with water and initially crushed using a blender and ground with a Retsch Grinder. The composites were melt blended using an internal mixer, molded with a hydraulic molding press and further cut into tensile dumbbell shaped specimens. At $7.5 \mathrm{wt} . \%$ the tensile strength improved by $5 \%$ but was inferior by $2 \%, 6 \%$ and $18 \%$ with additions of $15,22.5$ and $30 \mathrm{wt} . \%$, respectively compared to pure HDPE. The reduction in strengths above $15 \mathrm{wt}$.\% filler was due to a weaker interfacial adhesion as a result of increased agglomeration. In contrast, the Young's modulus increased progressively with filler loading by $8 \%, 20 \%, 28 \%$ and $31 \%$, respectively. The authors believed that the improvement was due to the eggshell powder being stiffer than the HDPE polymer [79].

Waste eggshell powder $(<75 \mu \mathrm{m})$ was also combined with virgin polystyrene (PS) in an amount of $20 \mathrm{wt} . \%$. The eggshell were washed, dried and ground to size. The ingredients were blended by melt-mixing in an internal mixer and the molded sheet composites were made by compression molding. The tensile strength and modulus of virgin PS (polystyrene 536), obtained from the supplier (Total Petrochemicals, Inc) was 44.8 MPa and 2.96 GPa, respectively (not reported in article). The composite tensile strength and Young's modulus were approximately $25 \mathrm{MPa}$ and $3.13 \mathrm{GPa}$, respectively, for a reduction of $44 \%$ and an increase of $5 \%$, respectively. This study focused on the amounts of recycled and virgin PS rather than varying the eggshell content [80].

Eggshell $(25 \mu \mathrm{m})$ loadings of 1, 2, 3, 4 and $5 \mathrm{wt}$.\% were added to polylactic acid (PLA). The eggshells were washed, dried and made into a fine powder using a kitchen grinder-mixer. PLA/eggshell films 
were produced via a film casting method by initially adding eggshell powders to PLA dissolved in chloroform. Both tensile strength and Young's modulus improved by $6 \%, 24 \%, 53 \%, 82 \%$ and $35 \%$ and $9 \%, 27 \%, 64 \%, 82 \%$ and $27 \%$, respectively, with increase in filler loading for all composite formulations. The authors proposed that the reductions at higher filler loadings ( $>4 \mathrm{wt} . \%$ ) were due to agglomeration of filler particles induced by van der Waals interactions [81]. In a related study, two eggshell particle sizes $(63 \mu \mathrm{m}$ and $32 \mu \mathrm{m})$ were incorporated into PLA in amounts of 5, 10 and $20 \mathrm{wt} . \%$. The eggshells were coarse crushed, washed with water, dried and ball milled to fine powders. Pellets for injection molding were produced using a twin screw extruder. Tensile strengths of $49.43 \mathrm{MPa}$ and $47.39 \mathrm{MPa}$ were obtained for $5 \mathrm{wt} . \%(32 \mu \mathrm{m})$ and $5 \mathrm{wt} . \%(63 \mu \mathrm{m})$ composites, respectively compared to pure PLA (51.52 MPa), which suggested slightly better mechanical properties for $32 \mu \mathrm{m}$ fillers. The Young's modulus improved with filler loadings and was maximum with $32 \mu \mathrm{m}$ particles at $20 \mathrm{wt} . \%$ (4.4 GPa) which was higher than pure PLA (3.6 GPa). The flexural strength increased up to $10 \mathrm{wt} . \%$ and reduced when more filler loadings were added, while flexural modulus presented an improvement with increase in filler loading up to a maximum of $20 \mathrm{wt} . \%$. For both flexural strength and flexural modulus, composites containing $32 \mu \mathrm{m}$ particle size fillers presented better properties. The flexural modulus increased by approximately $136 \%$. The authors suggested that the decrease in tensile and flexural strengths was due to particle agglomeration induced by electrostatic and van der Waals bonding forces at higher filler loading and larger particle sizes. They also suggested the increase in tensile modulus was due to inclusion of more rigid filler material and the increase in flexural modulus suggested improved resistance to deformation [82].

Table 6. Summary of thermoplastic polymers containing bio-calcium carbonate filler.

\begin{tabular}{|c|c|c|c|c|c|c|c|c|c|c|}
\hline PM & PT & FP/FT & $\mathrm{FZ}(\mu \mathrm{m})$ & FL & TS (MPa) & TE (GPa) & FS (MPa) & FE (GPa) & IT & Ref. \\
\hline \multirow{4}{*}{$\mathrm{PP}$} & \multirow{4}{*}{$\mathrm{IM}$} & \multirow{4}{*}{ Shellfish/NaOH } & \multirow{4}{*}{$<200(\mathrm{~nm})$} & 0 & 38 & 0.81 & - & - & - & \multirow{4}{*}{ [6] } \\
\hline & & & & 1 & 33 & 1.2 & - & - & - & \\
\hline & & & & 5 & 33 & 1.4 & - & - & - & \\
\hline & & & & 10 & 32 & 1.5 & - & - & - & \\
\hline \multirow{4}{*}{ PP } & \multirow{4}{*}{$\mathrm{IM}$} & \multirow{4}{*}{ Shellf/NaOH } & \multirow{4}{*}{$2-4$} & 5 & 33 & - & 39 & 1.4 & 6.1 & \multirow{4}{*}{ [48] } \\
\hline & & & & 7 & 32 & - & 42 & 1.6 & 6.5 & \\
\hline & & & & 10 & 31 & - & 44 & 1.7 & 6.8 & \\
\hline & & & & 15 & 30 & - & 42 & 1.8 & 6.5 & \\
\hline \multirow{6}{*}{ PP } & \multirow{6}{*}{$\mathrm{IM}$} & \multirow{6}{*}{ Snail shell/None } & \multirow{6}{*}{$<10$} & 5 & 32 & 1.3 & - & - & - & \multirow{6}{*}{ [83] } \\
\hline & & & & 10 & 31 & 1.5 & - & - & - & \\
\hline & & & & 15 & 31 & 1.6 & - & - & - & \\
\hline & & & & 20 & 30 & 1.7 & - & - & - & \\
\hline & & & & 25 & 29 & 1.8 & - & - & - & \\
\hline & & & & 30 & 29 & 2.0 & - & - & - & \\
\hline \multirow[b]{3}{*}{ LDPE } & \multirow[b]{3}{*}{$\mathrm{CM}$} & \multirow{3}{*}{$\begin{array}{l}\text { Cockle } \\
\text { shell/None }\end{array}$} & \multirow[b]{3}{*}{100} & 0 & 35 & 0.076 & - & - & - & \multirow[b]{3}{*}{ [84] } \\
\hline & & & & 7.5 & 42 & 0.14 & - & - & - & \\
\hline & & & & 15 & 37 & 0.16 & - & - & - & \\
\hline
\end{tabular}

Polymer material (PM) where Polypropylene (PP); Low density polyethylene (LDPE); Processing technique (PT) where Injection molding (IM); Compression molding (CM); Filler type (FP); Filler treatment (FT); Filler size (FZ); Filler loading (wt.\%) (FL); Tensile strength (TS); Young's modulus (TE); Flexural strength (FS); Flexural modulus (FE); Impact test (IT) where Charpy (C) or Izod (I). 
Table 7. Summary of thermoset polymers containing eggshell fillers.

\begin{tabular}{|c|c|c|c|c|c|c|c|c|c|c|c|}
\hline PM & RT & PT & FZ & FL & FT & TS (MPa) & TE (GPa) & FS (MPa) & FE (Gpa) & IT & Ref. \\
\hline \multirow{6}{*}{ E } & \multirow{6}{*}{$\mathrm{S}$} & \multirow{6}{*}{$\mathrm{SM}$} & \multirow{6}{*}{$1.0-9.0 \mu \mathrm{m}$} & & \multirow{6}{*}{$\mathrm{SH}$} & & & & & $\mathrm{C}$ & \multirow{6}{*}{ [85] } \\
\hline & & & & 0 & & - & - & - & - & 9.7 & \\
\hline & & & & 2 & & - & - & - & - & 16 & \\
\hline & & & & 5 & & - & - & - & - & 17 & \\
\hline & & & & 8 & & - & - & - & - & 14 & \\
\hline & & & & 10 & & - & - & - & - & 12 & \\
\hline \multirow{7}{*}{$\mathrm{E}$} & \multirow{7}{*}{$\mathrm{BB}$} & \multirow{7}{*}{ SM } & \multirow{7}{*}{$<100 \mathrm{~nm}$} & 0 & & - & - & 70 & 1.9 & - & \multirow{7}{*}{ [86] } \\
\hline & & & & 1 & & - & - & 75 & 2.2 & - & \\
\hline & & & & 2 & & - & - & 90 & 2.5 & - & \\
\hline & & & & 3 & ET & - & - & 91 & 2.6 & - & \\
\hline & & & & 4 & & - & - & 96 & 2.7 & - & \\
\hline & & & & 5 & & - & - & 79 & 2.2 & - & \\
\hline & & & & 6 & & - & - & 82 & 2.3 & - & \\
\hline \multirow{7}{*}{$\mathrm{E}$} & \multirow{7}{*}{$\mathrm{S}$} & \multirow{7}{*}{$\mathrm{RC}$} & \multirow{7}{*}{$50 \mathrm{~nm}$} & & \multirow{7}{*}{ SL } & & & & & I & \multirow{7}{*}{ [39] } \\
\hline & & & & 0 & & 28 & 2.5 & - & - & 0.65 & \\
\hline & & & & 1 & & 30 & 3.1 & - & - & 0.68 & \\
\hline & & & & 2 & & 54 & 3.6 & - & - & 0.75 & \\
\hline & & & & 3 & & 48 & 3.9 & - & - & 0.70 & \\
\hline & & & & 4 & & 44 & 4.1 & - & - & 0.69 & \\
\hline & & & & 5 & & 36 & 5.3 & - & - & 0.68 & \\
\hline \multirow{6}{*}{$\mathrm{E}$} & \multirow{6}{*}{$S$} & \multirow{6}{*}{ SM } & \multirow{6}{*}{$<50 \mu \mathrm{m}$} & & \multirow{6}{*}{$\mathrm{N}$} & & & & & I & \multirow{6}{*}{ [87] } \\
\hline & & & & 0 & & 46 & 3.6 & - & - & 1.6 & \\
\hline & & & & 5 & & 48 & 6.4 & - & - & 1.8 & \\
\hline & & & & 10 & & 52 & 5.9 & - & - & 2.0 & \\
\hline & & & & 15 & & 63 & 8.9 & - & - & 1.8 & \\
\hline & & & & 20 & & 53 & 8.4 & - & - & 1.7 & \\
\hline & & & & & & & & & & I & \\
\hline & & & & 0 & & 39 & 0.96 & 62 & 1.5 & 5.9 & \\
\hline$\Gamma$ & c & (GM & 500 & 5 & $\mathrm{~T}$ & 34 & 0.99 & 41 & 1.0 & 4.9 & [ee] \\
\hline $\mathrm{E}$ & $S$ & SM & $500 \mu \mathrm{m}$ & 10 & $\mathrm{~N}$ & 33 & 0.10 & 40 & 1.1 & 3.7 & [88] \\
\hline & & & & 15 & & 30 & 0.10 & 61 & 1.7 & 2.99 & \\
\hline & & & & 20 & & 26 & 0.95 & 53 & 1.3 & 2.5 & \\
\hline & & & & & & & & & & I & \\
\hline & & & & 0 & & 29 & 1.2 & 74 & - & 6.1 & \\
\hline & & & & 5 & & 34 & 1.6 & 75 & - & 6.5 & \\
\hline UP & $\mathrm{S}$ & HLU & $1.0-3.0 \mu \mathrm{m}$ & 10 & $\mathrm{~N}$ & 53 & 1.5 & 101 & - & 8.4 & [89] \\
\hline & & & & 15 & & 36 & 1.9 & 87 & - & 7.9 & \\
\hline & & & & 20 & & 31 & 1.7 & 72 & - & 7.5 & \\
\hline & & & & 25 & & 25 & 1.5 & 51 & - & 5.0 & \\
\hline
\end{tabular}

Polymer material (PM) where Epoxy (E); Unsaturated polyester (UP); Resin type (RT) where Synthetic (S); Bio-based (BB); Processing technique (PT) where Solution mixing (SM); Resin casting (RC); Hand lay-up (HLU); Filler size (FZ); Filler loading (wt.\%) (FL); Filler treatment (FT) where Sodium hydroxide (SH); Ethanol (ET); Sodium lauryl (SL); No treatment (N); Tensile strength (TS); Young's modulus (TE); Flexural strength (FS); Flexural modulus (FE); Impact test (IT) where Charpy (C) or Izod (I). 
Table 8. Summary of thermoset polymers containing seashell fillers (all by solution-mixing technique).

\begin{tabular}{|c|c|c|c|c|c|c|c|c|c|c|}
\hline PM & RT & FP/FT & FZ & FL & TS (MPa) & TE (GPa) & FS (MPa) & FE (GPa) & IT & Ref. \\
\hline \multirow{7}{*}{$\mathrm{E}$} & \multirow{7}{*}{ BB } & \multirow{7}{*}{ Mollusk/NaOH } & \multirow{7}{*}{$<250 \mu \mathrm{m}$} & & & & & & $\mathrm{C}$ & \multirow{7}{*}{ [63] } \\
\hline & & & & 0 & - & - & - & 2.1 & 13 & \\
\hline & & & & 5 & - & - & - & 2.2 & 1.9 & \\
\hline & & & & 10 & - & - & - & 2.7 & 1.7 & \\
\hline & & & & 20 & - & - & - & 3.2 & 1.3 & \\
\hline & & & & 30 & - & - & - & 3.3 & 1.3 & \\
\hline & & & & 40 & - & - & - & 3.1 & 1.1 & \\
\hline \multirow{6}{*}{$\mathrm{E}$} & \multirow{6}{*}{$\mathrm{S}$} & \multirow{6}{*}{ Cuttlebone/None } & \multirow{6}{*}{$15-25 \mu \mathrm{m}$} & 0 & 24 & 0.66 & - & - & - & \multirow{6}{*}{ [22] } \\
\hline & & & & 3 & 28 & 0.67 & - & - & - & \\
\hline & & & & 6 & 33 & 0.71 & - & - & - & \\
\hline & & & & 9 & 39 & 0.72 & - & - & - & \\
\hline & & & & 12 & 35 & 0.78 & - & - & - & \\
\hline & & & & 15 & 32 & 0.70 & - & - & - & \\
\hline \multirow{6}{*}{$\mathrm{E}$} & \multirow{6}{*}{$\mathrm{S}$} & \multirow{6}{*}{ Snail shell/None } & \multirow{6}{*}{$<50 \mu \mathrm{m}$} & & & & & & I & \multirow{6}{*}{ [87] } \\
\hline & & & & 0 & 46 & 3.6 & - & - & 1.6 & \\
\hline & & & & 5 & 59 & 6.5 & - & - & 1.8 & \\
\hline & & & & 10 & 69 & 6.4 & - & - & 1.9 & \\
\hline & & & & 15 & 61 & 6.7 & - & - & 1.7 & \\
\hline & & & & 20 & 51 & 7.9 & - & - & 1.7 & \\
\hline
\end{tabular}

Polymer material (PM) where Epoxy (E); Resin type (RT) where Bio-based (BB); Synthetic (S); Filler type (FP); Filler treatment (FT); Filler size (FZ); Filler loading (wt.\%) (FL); Tensile strength (TS); Young's modulus (TE); Flexural strength (FS); Flexural modulus (FE); Impact test (IT) where Charpy (C) or Izod (I).

\subsection{Thermoplastic Seashell Fillers}

The influence of seashell fillers incorporated into thermoplastic polymers on their mechanical properties have been investigated by a number of studies and are summarized in Table 6 . For instance, addition of seashell waste have been added to PP. Shellfish (SS) shell powder $(<200 \mathrm{~nm})$ was used to reinforce PP in the amounts of 1,3,5, and $10 \mathrm{wt} . \%$. The results were compared against commercial calcium carbonate having a particle size of $40-500 \mathrm{~nm}$. The SS were washed with water, coarsely ground, submitted to a $4 \%(w / v) \mathrm{NaOH}$ solution to eliminate the stratum corneum and further ball milled to produce fine powders. The two composites were compounded separately in a twin screw extruder and injection molded into tensile samples. For both composites the best tensile strengths obtained were with up to $5 \mathrm{wt} . \%$ fillers for a reduction of about 13\%. The Young's modulus was optimal at $10 \mathrm{wt} . \%$ and $5 \mathrm{wt} . \%$ for PP/SS and PP/calcium carbonate composites, respectively which increased by $85 \%$ and $79 \%$, respectively. In comparing the overall mechanical properties of both composites, $\mathrm{PP} / \mathrm{SS}$ composites presented better mechanical properties. The authors suggested that this may be due to organic matter present in the SS, which improved the bonding between the filler and matrix [6]. In a similar study, the properties of PP/SS composites containing SS powders $(2-4 \mu \mathrm{m})$ in amounts of 5,7 , $10,15,20$ and $30 \mathrm{wt} . \%$ were determined. The SS were washed, coarsely ground and immersed in $4 \%$ $(w / v) \mathrm{NaOH}$ solution to remove the stratum corneum and then ball milled. The PP and SS powders were mixed in a twin screw extruder, pelletized and injection molded into tensile, flexural and Charpy impact test specimens. The tensile strengths (Young's modulus not reported) reduced with increase in filler loadings by $3 \%, 6 \%, 9 \%, 12 \%, 15 \%$, and $21 \%$, respectively, compared to the pure PP. In contrast, the flexural strengths did not present a linear change. For example, strength improvements were observed at filler contents of $7,10,15$ and $20 \mathrm{wt} . \%$ by $2 \%, 7 \%, 2 \%$, and $5 \%$, respectively, but tended to decline by $5 \%$ and $2 \%$, when $5 \mathrm{wt} . \%$ and $30 \mathrm{wt} . \%$ filler contents were added, respectively. The flexural modulus improved with additions of filler loadings and was enhanced by $62 \%$ with $30 \mathrm{wt} . \%$ loading. The Charpy impact energy increased for all composite formulations by $5 \%, 12 \%, 17 \%, 12 \%, 14 \%$, and $16 \%$, respectively, with the optimum occurring at $10 \mathrm{wt} . \%$ loading. The authors attributed the decrease in tensile strength to poor filler-matrix adhesion which created weak interface regions and 
lower amounts of polymer material as a function of filler. Furthermore, the increase in flexural modulus was attributed to the augmented brittleness and stiffness of the composites [48].

Snail shell fillers were added to PP and the composite mechanical properties were compared with mineral calcium carbonate both with particle sizes less than $10 \mu \mathrm{m}$. The snail shells were initially washed with water and pulverized using a grinding disk mill machine. The ingredients were compounded in a twin screw extruder, pelletized and injection molded into tensile specimens. For 5, $10,15,20,25$ and $30 \mathrm{wt} . \%$ snail shell filler loadings, the tensile strengths decreased by approximately $0 \%, 3 \%, 3 \%, 6 \%, 9 \%$ and $9 \%$, respectively, while the Young's modulus increased by approximately $30 \%$, $50 \%, 60 \%, 70 \%, 80 \%$ and $100 \%$, respectively compared to pure PP. In comparison to bio- $\mathrm{CaCO}_{3}$, mineral calcium carbonate at a $30 \mathrm{wt} . \%$ filler loading presented a higher tensile strength and Young's modulus with a difference of $3 \%$. Since the tensile strength reductions were not substantial, the authors suggested a good dispersion/distribution of the particles and particle-matrix adhesion, while the increase in Young's modulus may have been due to higher particle rigidity compared to the PP matrix [83].

More recently, 10, 20, 30 and $40 \mathrm{pphr}(7.5,15,22.5$ and $30 \mathrm{wt} . \%)$ of cockle shells were blended into LDPE. The cockle shells were washed, dried, crushed and ground using a mill to $100 \mu \mathrm{m}$. The ingredients were melt blended using an internal mixer and the test specimens were molded using a hydraulic press. With 7.5 and $15 \mathrm{wt} . \%$ of cockle shells, the composites increased in tensile strength by $22 \%$ and $8 \%$, respectively, but decreased by $12 \%$ and $18 \%$ when 22.5 and $30 \mathrm{wt} . \%$ were added compared to pure LDPE. Although the composite Young's modulus is higher than the pure LDPE at all filler contents, it is optimal at 7.5 and $15 \mathrm{wt} . \%$. For example, at 7.5, 15, 22.5 and $30 \mathrm{wt} . \%$, the Young's modulus improved by $82 \%, 109 \%, 69 \%$ and $29 \%$, respectively. The improvement was attributed to good dispersion of the fillers which provided a greater surface area for the interaction between the fillers and the matrix. As particles cluster, stress concentrations begin to reduce the stress transfer from polymer chains to the fillers. The agglomeration was due to improper mixing at high loadings and incompatibility of the filler and polymer [84].

\subsection{Thermoset Eggshell Fillers}

A number of studies have been conducted on the addition of eggshell fillers in thermoset polymers and have evaluated their mechanical properties. The details are summarized in Table 7 . The Charpy impact toughness of synthetic epoxy resin was improved by incorporating eggshell fillers $(1-9 \mu \mathrm{m})$ in amounts of 2, 5, 8 and $10 \mathrm{wt} . \%$. The inner membranes were initially manually removed from the fresh eggshells. The eggshells were washed, vacuum dried and ground into powder using a planetary ball mill. The powders were then immersed in $4 \% \mathrm{NaOH}$ and dried. The composites were produced using a solution mixing method to disperse the fillers in a mixture of acetone and liquid epoxy. After heating to remove the solvent, the mixture was poured into a steel mold coated with a release agent. The composites were cured at $90^{\circ} \mathrm{C}$ for $2 \mathrm{~h}$ and at $150{ }^{\circ} \mathrm{C}$ for $5 \mathrm{~h}$. The Charpy impact toughness increased by approximately $65 \%, 75 \%, 44 \%$ and $24 \%$, respectively, compared to pure epoxy. This improvement was due to enhanced interaction between the matrix and the particles [85]. Another investigation determined the effect of nano-eggshell particle $(<100 \mathrm{~nm})$ filler loadings of $1,2,3,4,5$ and $10 \mathrm{wt} . \%$ on the flexural properties of a bio-epoxy resin. The eggshells were initially boiled at $100{ }^{\circ} \mathrm{C}$ for $6 \mathrm{~h}$, reduced in size using a laboratory blender, washed with water, ethanol and dried. The particles were further ball milled, washed with ethanol and centrifuged. Ethanol was again added to the eggshell particles, magnetically stirred and irradiated with ultrasound followed by centrifuging and vacuum drying. The composites were fabricated via a solution-mixing method. The mixtures were poured into silicone molds, cured at room temperature for $2 \mathrm{~h}$ and post-cured at $48.8^{\circ} \mathrm{C}$ for $2 \mathrm{~h}$. The test results presented an improvement in both flexural strength and flexural modulus for all composites in comparison to the pure bio-resin. For example, the flexural strength and flexural modulus improved by $7-37 \%$ and $16-42 \%$, respectively. The composites exhibited similar results in both properties for a filler loading of $4 \mathrm{wt} . \%$ as the optimum. The authors reported that the improvement in these properties were 
due to enhanced interaction between the filler and matrix caused by the hydrogen bonding promoted by amine, carboxylic, and hydroxyl functional groups in eggshells [86].

In another work, nano-eggshell $(50 \mathrm{~nm}$ ) bio-fillers were added in amounts of 1, 2, 3, 4, and $5 \mathrm{wt} . \%$ in a synthetic epoxy resin. The eggshells were washed with water and disinfected with sodium hypochlorite followed by vacuum drying. The eggshells were made into a coarse powder using a blender and $5 \mathrm{wt} . \%$ sodium lauryl surfactant was added in order to enhance the dispersion and adhesion with the epoxy. The eggshells were then dry ball milled to the final powder size. The composites were made using a resin-casting method, in which the resin and fillers were mixed in an electric shear mixer, and cast onto a glass mold containing a wax release agent. The composites were cured at room temperature for $24 \mathrm{~h}$. The tensile strength, tensile modulus and Izod impact energy improved by 7-93\%, $24-112 \%$ and $5-15 \%$, respectively. The optimal tensile strength and impact toughness was obtained for $2 \mathrm{wt} . \%$ filler loading and the tensile modulus was highest with $5 \mathrm{wt} . \%$. The authors suggested that the increase in tensile strength and impact toughness was due to the nano-sized particles having high surface areas and better adhesion to the matrix material, while the increase in tensile modulus was due to the inclusion of stiffer filler nanoparticles compared to the matrix material [39].

In a recent study, eggshells $(5,10,15$ and $20 \mathrm{wt} . \%)$ were blended into a synthetic epoxy matrix. The eggshells were washed with hot water, dried and milled with a planetary ball mill to a size $<50 \mu \mathrm{m}$. Composites were fabricated using a casting method by first heating the epoxy to $65^{\circ} \mathrm{C}$, adding the eggshells and stirring at $500 \mathrm{rpm}$ for 1 hour. After cooling to room temperature, the catalyst was added, mixed and poured into plastic molds coated with wax for easier removal after two days of curing. The tensile strengths and Young's modulus improved by 5\%, $12 \%, 36 \%$ and $16 \%$ as well as by $74 \%$, $63 \%, 144 \%$ and $130 \%$, respectively, while un-notched Izod impact tests increased by $12 \%, 28 \%, 13 \%$ and $11 \%$, respectively, compared to the pure epoxy resin. Improvements in properties were due to homogeneous dispersion of the shell particles within the epoxy [87]. Similarly, eggshell powder in amounts of 5, 10, 15 and $20 \mathrm{wt} . \%$ were combined with a synthetic epoxy resin. The eggshells were washed, dried and crushed to a fine powder $(500 \mu \mathrm{m})$. The composites were prepared by adding a fixed amount of epoxy and eggshells to a beaker and stirred at $200 \mathrm{rpm}$. The curing agent was then added, stirred and poured into a wax coated mold. The tensile strength reduced by $13 \%, 15 \%, 23 \%$ and $33 \%$, respectively, while the tensile modulus improved by $3 \%, 4 \%, 8 \%$, respectively but decreased by $1 \%$ at $20 \mathrm{wt} . \%$ loading. The reduced tensile strength was due to poor adhesion of filler-matrix and agglomeration which creates stress concentrations. This is magnified by the increased filler loadings. Similarly, 5-15 wt.\% of eggshell fillers increased the stiffness of the epoxy while reductions were observed with additions of $20 \mathrm{wt} . \%$ due to aggregation of particles. The flexural strength decreased by $34 \%, 35 \%, 1 \%$ and $15 \%$, respectively. The flexural modulus dropped by $30 \%$ and $23 \%$ for 5 and $10 \mathrm{wt} . \%$, respectively but increased by $13 \%$ at a $15 \mathrm{wt} . \%$ loading. A further increase to $20 \mathrm{wt} . \%$ filler content reduced the modulus by $12 \%$. The reductions are thought to be a result of improper mixing of the fillers within the epoxy which led to a poor dispersion in addition to weak bonding between the filler particles and matrix. The Izod impact strength gradually decreased as the filler loading increased by $17 \%, 37 \%, 51 \%$ and $58 \%$, respectively, which suggests adding eggshell fillers was not beneficial for improving toughness of the epoxy [88].

Unsaturated polyester/eggshell (1-3 $\mu \mathrm{m})$ and unsaturated polyester/commercial calcium carbonate (3-8 $\mu \mathrm{m})$ composite films were produced that contained filler loadings of 5, 10, 15, 20 and $25 \mathrm{wt} . \%$. The eggshells were washed in water, sterilized, dried, crushed in an electric blender and reduce in size using a mortar and pestle. The films were produced via a hand lay-up technique and a hot press. The tensile strength for unsaturated polyester/eggshell films increased by $17 \%, 83 \%, 24 \%, 7 \%$ and $14 \%$, respectively, compared to unsaturated polyester/commercial calcium carbonate which increased by $1 \%, 69 \%, 19 \%, 7 \%$ and $12 \%$, respectively. The Young's modulus for unsaturated polyester/eggshell composites increased by approximately $33 \%, 25 \%, 58 \%, 42 \%$ and $25 \%$, respectively, in contrast to the unsaturated polyester/commercial calcium carbonate which increased by $27 \%, 47 \%, 15 \%, 13 \%$ and $8 \%$, respectively. The flexural strengths (flexural modulus not reported) for the unsaturated 
polyester/eggshell films increased by approximately $1 \%, 37 \%$ and $18 \%$ with 5,10 , and $15 \mathrm{wt} . \%$ filler contents, respectively, however, above $15 \mathrm{wt} . \%$ the flexural strengths reduced. In a similar way, the unsaturated polyester/calcium carbonate flexural strengths increased by $0.3 \%, 32 \%$ and $10 \%$, respectively, and further decreased above $15 \mathrm{wt} . \%$. For both composites, the Izod impact toughness increased with an increase in filler loading up to $20 \mathrm{wt} . \%$ and further decreased at $25 \mathrm{wt} . \%$ loading. The authors suggested that improvements in tensile strengths were due to good interfaces and strong bonding between the filler particles and resin, while reductions at higher loadings were a result of increased void contents and increased brittle effect of the filler material leading to toughness reductions [89].

\subsection{Thermoset Seashell Fillers}

Limited studies have added seashell fillers to thermoset resins as given in Table 8. For instance, bio-epoxy composites were produced with mollusks shells of particle sizes $<250 \mu \mathrm{m}$ and filler amounts of 5, 10, 20, 30 and $40 \mathrm{wt.} \%$. The mollusks were washed with $4 \%$ sodium hydroxide, dried and ground using an ultra-centrifugal mill. The powders were then treated with a silane solution to improve the chemical interaction between the filler and the matrix. The composites were made via a solution mixing method, poured in a polytetrafluoroethylene mold and cured at $100{ }^{\circ} \mathrm{C}$ for $45 \mathrm{~min}$. The flexural modulus (flexural strength not reported) increased by 5\%,29\%, 52\%, 57\% and $48 \%$ with increase in filler loading. In contrast, the Charpy energy drastically decreased at all filler loadings by $85 \%, 87 \%$, $90 \%, 90 \%$ and $92 \%$, respectively. The flexural modulus improved due to a homogeneous dispersion, polymer chain mobility restriction, but at higher filler loadings the dispersion was reduced and some aggregates were formed leading to the presence of stress concentrators. The dispersion and interaction of the filler particles within the matrix play a role in mechanical properties, but the amount of fillers were not an indicator for the drop in impact energy [63]. In a related study, the effect of cuttlebone shells $(15-25 \mu \mathrm{m})$ and commercial calcium carbonate $(<10 \mu \mathrm{m})$ fillers in loadings of 3, 6, 9, 12 and $15 \mathrm{wt} . \%$ in a synthetic epoxy were compared. Cuttlebones were washed with water, scrubbed with a steel brush and dried, followed by crushing and grinding using a pulverizer. One batch of cuttlebone powders were used as prepared (CB) and another batch were heated to $400^{\circ} \mathrm{C}$ for $3 \mathrm{~h}$. The composites were made via a hand lay-up method. The mixture was poured into a steel mold with an applied release agent and cured at room temperature for $24 \mathrm{~h}$, demolded and post-cured at $80^{\circ} \mathrm{C}$ for $4 \mathrm{~h}$. The tensile strengths for epoxy/CB, epoxy/heated $\mathrm{CB}$ and epoxy/calcium carbonate composites increased by $17 \%$, $38 \%, 63 \%, 46 \%$ and $33 \%$ and by $25 \%, 54 \%, 72 \%, 67 \%$ and $46 \%$ as well as by $4 \%, 8 \%, 42 \%, 13 \%$ and $8 \%$, respectively. Similarly, the Young's modulus for epoxy/CB and epoxy/heated CB increased by $2 \%, 8 \%, 9 \%, 18 \%$ and $6 \%$ and $0.2 \%, 7 \%, 12 \%, 27 \%$ and $35 \%$, respectively. However, epoxy/calcium carbonate composite Young's modulus was less affected by the fillers and increased by $0.2 \%, 6 \%, 3 \%$, and $1 \%$ but decreased by $7 \%$ at $15 \mathrm{wt} . \%$. The authors suggested that the improved tensile strength was due to good interaction between the filler and matrix, while beyond $9 \mathrm{wt} . \%$ the fillers had poor dispersion with the matrix. In addition, the Young's modulus had good adhesion between the filler and matrix but reductions occurred due to agglomeration [22]. More recently, snail shells were mixed into a synthetic epoxy resin. The snail shells were soaked for seven hours in $5 \%$ diluted household sodium hypochlorite, rinsed with distilled water and dried. The shells were then ball milled to a size of $<50 \mu \mathrm{m}$. The composites were made using a conventional casting method as explained earlier. As compared to the unfilled epoxy, the tensile strengths, Young's modulus and Izod impact tests were improved by $28 \%, 49 \%, 32 \%$ and $32 \%$, by $79 \%, 76 \%, 83 \%$ and $119 \%$, and by $11 \%, 20 \%, 10 \%$ and $7 \%$, respectively. The increase in tensile strengths, Young's modulus and impact strengths were due to the high carbon content present in the snail shells which produced a tougher and stronger structure as well as the size, shape and interconnectivity formed by the particles [87].

The addition of mineral fillers to polymers is generally to reduce the cost of the composite and may or may not improve the mechanical properties. The hydrophilic property of mineral calcium carbonate renders it incompatible with hydrophobic polymers. In an effort to improve compatibility, reduce 
agglomeration, improve bonding and enhance the mechanical properties of polymer composites, calcium carbonate surface modifiers have been studied. The modifiers play a role in linking the inorganic filler with the organic polymer. It is important to note that an excess amount of coating could negatively affect the mechanical properties [90]. Differential thermal gravimetric analysis (DTG) can be used to differentiate between a single (thin) coated layer and multiple (thick) layers [91,92]. The most common fatty acid coating applied is stearic acid [91] while other modifiers have been polyacrylic acid [93], phosphate [94], acrylic acid [95], silane [96], dendritic carboxylic acid [97], titanate [98] and zirconate [99]. Several studies exist on bio-calcium carbonate eggshell. For instance, eggshells have been modified with propionic acid (i.e., carboxylic acid) [100], silane [42,85,101], titanate [42], zirconate [42], stearic acid [73,102,103], isophthalic acid [74,78], maleic anhydride [104], pimelic acid [72] and a solid state shear pulverization process (without chemical modification) [105]. Limited studies have been conducted on seashells. For example, seashells have been treated with silane [63,106,107], stearic acid [108], titanate [109] and pimelic acid [110,111]. In general, the majority of studies found improvements in mechanical properties with applications of surface modifiers.

\section{Discussion and Knowledge Gaps}

Based on this review, the addition of bio-calcium carbonate fillers could successfully be used in polymer composites to improve mechanical properties. Generally, the studies obtained their bio- fillers in powder form by grinding/pulverizing using small-scale laboratory processes generally as a 'proof of concept". Although a number of recycling processes for waste eggshells have been proposed [112], medium- to large-scale industrial operations have not been in operation to date to recycle eggshells and seashells into useful powders. The enormous amounts of eggshells and seashells generated everyday by their respective industries are difficult to compost and for the most part are considered waste for landfills. In addition, the unpleasant smell generated from decaying organic material in the shells makes it difficult to distribute on the land. As nearby lands become saturated, hauling of the waste comes at a cost to the company. More importantly, in certain countries (e.g., the US) this form of disposal may not be permitted [113] and landfilling may be the only option.

Bio-fillers could potentially replace and/or substitute mineral limestone added to polymers to reduce their cost while still improving their mechanical properties. This review illustrated the bio-calcium carbonate filler (uncoated/unmodified) loadings played an important role on the mechanical properties of the matrix polymers. The trend for thermoplastics composites containing bio-fillers tended to reduce in tensile strength with filler loading but were acceptable with $5 \mathrm{wt} . \%$ bio-fillers, while the flexural strengths were ideal with 5-10 wt.\% loadings. Both Young's modulus and flexural modulus improved with filler loadings and were optimal at the higher contents. The impact toughness showed $10 \mathrm{wt} . \%$ loadings were the best. Similarly, thermoset composite tensile and flexural strengths decreased with filler loading but were ideal with not more than $10 \mathrm{wt} . \%$ fillers. The Young's modulus and flexural modulus were ideal up to $15 \mathrm{wt} . \%$ fillers. The impact toughness decreased at all filler loadings but recommendations of less than $10 \mathrm{wt} . \%$ were suitable. Common improvements in properties were credited to homogeneous particle dispersion/distribution, polymer chain mobility restrictions, enhanced interaction, good interface and better adhesion/bonding between the filler particles and matrix. In contrast, the general observations for the deterioration of mechanical properties were attributed to poor compatibility of the hydrophobic polymer with hydrophilic bio-calcium carbonate fillers, poor adhesion/bonding of the filler-matrix, and agglomeration induced by electrostatic and van der Waals bonding forces of bio-calcium carbonate particles which amplified at higher filler loadings. The composite modulus improvements were a result of inclusion of stiffer and more rigid particles than the polymer matrix. The particle size were very different from study to study and ranged from micro- to nano-meter scale where properties largely improved for smaller sizes. A few studies conducted on eggshell and seashell fillers suggested hydrogen bonding between the matrix and filler were promoted by amine, carboxylic, and hydroxyl functional groups from the membrane on eggshells 
and organic matter in the seashells which may have contributed/improved the bonding between the filler and matrix.

Bio-calcium carbonate has not been commercialized to date possibly due to an absence of proper management systems for recuperating and processing waste eggshells or seashells. The lack of recycling facilities in many countries may also be hindered from end-user demand. The quick decay of organic material within the eggshells and seashells may limit the locations of recovery units to the processors. A map of eggshell and seashell processors within each country would help identify key actors and link smaller companies to better manage this waste into central locations. The driving force for adoption of new materials such as bio-calcium carbonates by industry is their cost, availability, continuous supply and performance which is unknown at this time. Additions of mineral limestone fillers in polymers has been the norm in the plastics industry for many years and changing to new materials can be difficult without its familiarity. Generating eggshell and seashell processing procedures and standards may help implement the use of bio-calcium carbonate, particularly in composite materials.

Universally, the literature is not clear if organic membranes should be removed from eggshells/seashells by heating or by use of chemicals or do they interact favorably with the polymers. Particle surface modifiers could be applied to eggshell and seashell fillers but more work should be conducted in this area to optimize the coating thickness relative to cost. A study could be conducted on the viability of a closed system that could heat eggshells and/or seashells above $750{ }^{\circ} \mathrm{C}$ in order to form into calcium oxide and further react with carbon dioxide (collected from $\mathrm{CaO}$ formation) to form a purified form of calcium carbonate without any organic membranes. Purified forms of calcium carbonate could be used in many other markets/industries such as pet food, pharmaceutical, mortars and concrete, production of lime and hydroxyapatite for dentistry and medical applications. Another challenge is to investigate the possibility of a calcium carbonate recovery unit for the seashell industry similar to current egg breaking plant undertakings. A final knowledge gap in this area is to carry out techno-economic analysis and life-cycle analysis studies on the recovery of waste eggshells and seashells for strategic regions.

\section{Conclusions}

The review of bio-calcium carbonate fillers in polymers has gained the attention of industry and researchers. The analyses showed improvements in composite materials with the addition of fillers (even without surface modifications) compared to pure polymer matrices. Upcoming research and development should focus on improving the properties of bio-polymers with bio-calcium carbonate fillers to make them competitive with synthetic polymers. Recently, there has been small-scale egg-breaking plants partnering with universities in an effort to industrialize waste eggshell recuperation at their facilities. With suitable cleaning and grinding equipment, waste eggshells and seashells have potential to be recycled for a variety of applications. Processing these bio-materials could have minimal impact on the environment provided a closed-loop recovery system is used. At present recycling is not an option for waste eggshell and seashell industry producers. Once investments are made in research, facilities and infrastructure and the supply of bio-calcium carbonate becomes accessible, perhaps market demand will follow.

Author Contributions: The following statements should be used conceptualization, S.O. and D.C.; methodology, D.C.; formal analysis, S.O.; investigation, S.O.; resources, D.C.; data curation, S.O and D.C..; writing-original draft preparation, S.O.; writing-review and editing, D.C.; supervision, D.C.; project administration and funding acquisition, D.C., please turn to the CRediT taxonomy for the term explanation. All authors have read and agreed to the published version of the manuscript.

Funding: This research was funded by the Natural Sciences and Engineering Research Council of Canada (NSERC) Discovery Grant RGPIN-2020-06701. The APC was funded by MDPI.

Conflicts of Interest: The authors declare no conflict of interest. 


\section{References}

1. Morris, J.P.; Thierry, B.; Gauthier, C. Shells from aquaculture: A valuable biomaterial, not a nuisance waste product. Rev. Aquac. 2019, 11, 42-57. [CrossRef]

2. Cordeiro, M.M.C.; Maxwell, T.H. Recent patents on eggshell: Shell and membrane applications. Recent Pat. Food Nutr. Agric. 2011, 3, 1-8. [CrossRef]

3. Jovic, M.; Mandic, M.; Sljivic-Ivanovic, M.; Smiciklas, I. Recent trends in application of shell waste from mariculture. Stud. Mar. 2019, 32, 47-62. [CrossRef]

4. Hart, A. Mini-review of waste shell-derived materials' applications. Waste Manag. Res. 2020. [CrossRef]

5. Felipe-Sesé, M.; Eliche-Quesada, D.; Corpas-Iglesias, F.A. The use of solid residues derived from different industrial activities to obtain calcium silicates for use as insulating construction materials. Ceram. Int. 2011, 37, 3019-3028. [CrossRef]

6. Li, H.Y.; Tan, Y.Q.; Zhang, L.; Zhang, Y.X.; Song, Y.H.; Ye, Y.; Xia, M.S. Bio-filler from waste shellfish shell: Preparation, characterization, and its effect on the mechanical properties on polypropylene composites. J. Hazard. Mater. 2012, 217, 256-262. [CrossRef]

7. Yoon, G.L.; Kim, B.T.; Kim, B.O.; Han, S.H. Chemical-mechanical characteristics of crushed oyster-shell. Waste Manag. 2003, 23, 825-834. [CrossRef]

8. Das, K.C.; Minkara, M.Y.; Melear, N.D.; Tollner, E.W. Effect of poultry litter amendment on hatchery waste composting. J. Appl. Poult. Res. 2002, 11, 282-290. [CrossRef]

9. Bee, S.L.; Abdul, H.Z.A. Hydroxyapatite derived from food industry bio-wastes: Syntheses, properties and its potential multifunctional applications. Ceram. Int. 2020, 46, 17149-17175. [CrossRef]

10. Sawai, J. Antimicrobial characteristics of heated scallop shell powder and its application. Biocontrol Sci. 2011, 16, 95-102. [CrossRef] [PubMed]

11. Hecht, J. Eggshells break into collagen market. New Sci. 1999, 161, 6.

12. Shellbrane Project. Co-Funded by the European Commission through the Seventh Framework Programme (FP7) through the Funding Scheme "Research for the Benefit of SME-s" under Grant Agreement No. 286910. 2012. Available online: https://cordis.europa.eu/error500 (accessed on 3 February 2020).

13. Tripathi, A.D.; Mishra, R.; Maurya, K.K.; Singh, R.B.; Wilson, D.W. Estimates for world population and global food availability for global health. In The Role of Functional Food Security in Global Health; Academic Press: Cambridge, MA, USA, 2019; pp. 3-24. [CrossRef]

14. Sonenklar, C. Famous for egg waste. In Research/Penn State News; Penn State University: State College, PA, USA, 1999; Volume 20, pp. 1-2. Available online: https://news.psu.edu/story/140891/1999/09/01/research/ famous-egg-waste (accessed on 15 March 2020).

15. Hseih, J. Researchers develop process to recover eggshell waste for alternative uses. Poult. Tech. 2007, $19,1$.

16. Morris, J.P.; Wang, Y.; Backeljau, T.; Chapelle, G. Biomimetic and bio-inspired uses of mollusc shells. Mar. Genom. 2016, 27, 85-90. [CrossRef] [PubMed]

17. Gil-Quintana, E.; Fenaux, M.; Nuez, M.L.; Molero, A.; Aguirre, A. Short-term effects of ovomet ${ }^{\circledR}$, eggshell membrane. Joint pain: A double-blind and placebo study. J. Osteopor. Phys. Act. 2018, 6, 2. [CrossRef]

18. Shearman, S. Scotch egg company claims to have cracked problem of eggshell waste. Guard $2016,1$. Available online: https://www.theguardian.com/sustainable-business/2016/jun/30/scotch-egg-companycracked-eggshell-waste-problem-recycling-plastic (accessed on 19 March 2020).

19. Gettens, R.J.; FitzHugh, E.W.; Feller, R.L. Calcium carbonate whites. Stud. Conserv. 1974, 19, $157-184$. [CrossRef]

20. Cölfen, H. Precipitation of carbonates: Recent progress in controlled production of complex shapes. Curr. Opin. Colloid Interface Sci. 2003, 8, 23-31. [CrossRef]

21. Patnaik, P. Handbook of Inorganic Chemicals; McGraw-Hill: New York, NY, USA, 2003; ISBN 0-07-049439-8.

22. Periasamy, K.; Mohankumar, G.C. Sea coral-derived cuttlebone reinforced epoxy composites: Characterization and tensile properties evaluation with mathematical models. J. Compos. Mater. 2016, 50, 807-823. [CrossRef]

23. Cao, Z.; Daly, M.; Clémence, L.; Geever, L.M.; Major, I.; Higginbotham, C.L.; Devine, D.M. Chemical surface modification of calcium carbonate particles with stearic acid using different treating methods. Appl. Surf. Sci. 2016, 378, 320-329. [CrossRef] 
24. Tyler, C.; Simkiss, K.A. Study of the Egg Shells of Ratite Birds. In Proceedings of the Zoological Society of London, Regent's Park, London, UK, 8 December 1959; Blackwell Publishing Ltd.: Oxford, UK, 1959; Volume 133, pp. 201-243. [CrossRef]

25. DSM Nutritional Products Ltd. A Practical Guide to the Efficient Evaluation of Egg Quality at Farm Level in: DSM Egg Quality Manual; DSM Nutritional Products Ltd.: Basel, Switzerland, 2018; pp. 1-16.

26. John-Jaja, S.A.; Udoh, U.H.; Nwokolo, S.C. Repeatability estimates of egg weight and egg-shell weight under various production periods for bovan nera black laying chicken. Beni-Suef Univ. J. Basic Appl. Sci. 2016, 5, 389-394. [CrossRef]

27. Stadelman, W.J. Eggs and Egg Products. In Encyclopedia of Food Science and Technology; Francis, F.J., Ed.; Wiley: New York, NY, USA, 2000; pp. 593-599.

28. Mittal, A.; Teotia, M.; Soni, R.K.; Mittal, J. Applications of egg shell and egg shell membrane as adsorbents: A review. J. Mol. Liq. 2016, 223, 376-387. [CrossRef]

29. Stadelman, W.J.; Cotterill, O. Egg Science and Technology, 4th ed.; CRC Press: Boca Raton, FL, USA, 1995; ISBN 9781560228554.

30. Solomon, S.E. The eggshell: Strength, structure and function. Br. Poult. Sci. 2010, 51, 52-59. [CrossRef] [PubMed]

31. Cree, D.; Rutter, A. Sustainable bio-Inspired limestone eggshell powder for potential industrialized applications. ACS Sustain. Chem. Eng. 2015, 3, 941-949. [CrossRef]

32. Betancourt, N.; Cree, D. Mechanical properties of poly (lactic acid) composites reinforced with $\mathrm{CaCO}_{3}$ eggshell based fillers. Mater. Res. Soc. 2017, 3, 6-11. [CrossRef]

33. Parsons, A.H. Structure of the eggshell. Poult. Sci. 1982, 61, 2013-2021. [CrossRef]

34. Ketta, M.; Tůmová, E. Eggshell structure, measurements, and quality-affecting factors in laying hens: A review. Czech J. Anim. Sci. 2016, 61, 299-309. [CrossRef]

35. Tsai, W.T.; Yang, J.M.; Lai, C.W.; Cheng, Y.H.; Lin, C.C.; Yeh, C.W. Characterization and adsorption properties of eggshells and eggshell membrane. Bioresour. Technol. 2006, 97, 488-493. [CrossRef]

36. Cree, D.; Pliya, P. Effect of elevated temperature on eggshell, eggshell powder and eggshell powder mortars for masonry applications. J. Build. Eng. 2019, 100852. [CrossRef]

37. Tsuboi, Y.; Koga, N. Thermal decomposition of biomineralized calcium carbonate: Correlation between the thermal behavior and structural characteristics of avian eggshell. ACS Sustain. Chem. Eng. 2018, 6, 5283-5295. [CrossRef]

38. Intharapat, P.; Kongnoo, A.; Kateungngan, K. The potential of chicken eggshell waste as a bio-filler filled epoxidized natural rubber (ENR) composite and its properties. J. Polym. Environ. 2013, 21, 245-258. [CrossRef]

39. Mohan, T.P.; Kanny, K. Thermal, mechanical and physical properties of nano egg shell particle-filled epoxy nanocomposites. J. Compos. Mater. 2018, 52, 3989-4000. [CrossRef]

40. Krishna, D.S.R.; Siddharthan, A.; Seshadri, S.K.; Kumar, T.S. A novel route for synthesis of nanocrystalline hydroxyapatite from eggshell waste. J. Mater. Sci. Mater. Med. 2007, 18, 1735-1743. [CrossRef] [PubMed]

41. Pliya, P.; Cree, D. Limestone derived eggshell powder as a replacement in portland cement mortar. Constr. Build. Mater. 2015, 95, 1-9. [CrossRef]

42. Boronat, T.; Fombuena, V.; Garcia-Sanoguera, D.; Sanchez-Nacher, L.; Balart, R. Development of a biocomposite based on green polyethylene biopolymer and eggshell. Mater. Des. 2015, 68, 177-185. [CrossRef]

43. Beck, K.; Brunetaud, X.; Mertz, J.D.; Al-Mukhtar, M. On the use of eggshell lime and tuffeau powder to formulate an appropriate mortar for restoration purposes. Geol. Soc. Lond. Spec. Publ. 2010, 331, 137-145. [CrossRef]

44. Okonkwo, U.N.; Odiong, I.C.; Akpabio, E.E. The effects of eggshell ash on strength properties of cement-stabilized lateritic. Int. J. Sustain. Constr. Eng. Technol. 2012, 3, 18-25.

45. Koudele, J.W.; Edwin, C.H. The egg products industry of the United States: Part I-historical highlights, 1900-1959. Kans. Agric. Expt. Stn. Bull. 1960, 423, 1-46.

46. Wu, J. Eggs and Egg Products Processing. In Food Processing: Principles and Applications, 2nd ed.; John Wiley \& Sons, Ltd.: Hoboken, NJ, USA, 2014; pp. 437-455. [CrossRef]

47. FAO (Food and Agriculture Organization of the United Nations). Corporate Statistical Database. 2017. Available online: http://www.fao.org/faostat/en/\#data/CL (accessed on 6 May 2020). 
48. Yao, Z.T.; Chen, T.; Li, H.Y.; Xia, M.S.; Ye, Y.; Zheng, H. Mechanical and thermal properties of polypropylene (PP) composites filled with modified shell waste. J. Hazard. Mater. 2013, 262, 212-217. [CrossRef]

49. Barros, M.C.; Bello, P.M.; Bao, M.; Torrado, J.J. From waste to commodity: Transforming shells into high purity calcium carbonate. J. Clean. Prod. 2009, 17, 400-407. [CrossRef]

50. Moustafa, H.; Youssef, A.M.; Duquesne, S.; Darwish, N.A. Characterization of bio-filler derived from seashell wastes and its effect on the mechanical, thermal, and flame retardant properties of ABS composites. Polym. Compos. 2017, 38, 2788-2797. [CrossRef]

51. Yao, Z.; Xia, M.; Li, H.; Chen, T.; Ye, Y.; Zheng, H. Bivalve shell: Not an abundant useless waste but a functional and versatile biomaterial. Crit. Rev. Environ. Sci. Technol. 2014, 44, 2502-2530. [CrossRef]

52. Jung, J.H.; Shon, B.H.; Yoo, K.S.; Oh, K.J. Physicochemical characteristics of waste sea shells for acid gas cleaning absorbent. Korean J. Chem. Eng. 2000, 17, 585-592. [CrossRef]

53. Lertwattanaruk, P.; Makul, N.; Siripattarapravat, C. Utilization of ground waste seashells in cement mortars for masonry and plastering. J. Environ. Manag. 2012, 111, 133-141. [CrossRef] [PubMed]

54. Olivia, M.; Oktaviani, R. Properties of concrete containing ground waste cockle and clam seashells. Procedia Eng. 2017, 171, 658-663. [CrossRef]

55. Zhong, B.Y.; Zhou, Q.; Chan, C.F.; Yu, Y. Structure and property characterization of oyster shell cementing material. Jiegou Нuaxue 2012, 31, 85-92.

56. Tudor, H.E.; Gryte, C.C.; Harris, C.C. Seashells: Detoxifying agents for metal-contaminated waters. Water Air Soil Pollut. 2006, 173, 209-242. [CrossRef]

57. Mohamed, M.; Yusup, S.; Maitra, S. Decomposition study of calcium carbonate in cockle shell. J. Eng. Sci. Technol. 2012, 7, 1-10.

58. Olivia, M.; Mifshella, A.A.; Darmayanti, L. Mechanical properties of seashell concrete. Procedia Eng. 2015, 125, 760-764. [CrossRef]

59. Martínez-García, C.; González-Fonteboa, B.; Martínez-Abella, F.; Carro-López, D. Performance of mussel shell as aggregate in plain concrete. Constr. Build. Mater. 2017, 139, 570-583. [CrossRef]

60. Yoon, H.; Park, S.; Lee, K.; Park, J. Oyster shell as substitute for aggregate in mortar. Waste Manag. Res. 2004, 22, 158-170. [CrossRef]

61. Safi, B.; Saidi, M.; Daoui, A.; Bellal, A.; Mechekak, A.; Toumi, K. The use of seashells as a fine aggregate (by sand substitution) in self-compacting mortar (SCM). Constr. Build. Mater. 2015, 78, 430-438. [CrossRef]

62. Yang, E.I.; Yi, S.T.; Leem, Y.M. Effect of oyster shell substituted for fine aggregate on concrete characteristics: Part I. fundamental properties. Cem. Concr. Res. 2005, 35, 2175-2182. [CrossRef]

63. Fombuena, V.; Bernardi, L.; Fenollar, O.; Boronat, T.; Balart, R. Characterization of green composites from biobased epoxy matrices and bio-fillers derived from seashell a wastes. Mater. Des. 2014, 57, 168-174. [CrossRef]

64. De Alvarenga, R.A.F.; Galindro, B.M.; de Fátima Helpa, C.; Soares, S.R. The recycling of oyster shells: An environmental analysis using life cycle assessment. J. Environ. Manag. 2012, 106, 102-109. [CrossRef] [PubMed]

65. Fischer, H. Shell weight as an independent variable in relation to cadmium content of mollusks. Mar. Ecol. Prog. Ser. Oldendorf. 1983, 12, 59-75. [CrossRef]

66. Palmer, A.R. Calcification in marine molluscs: How costly is it? Proc. Natl. Acad. Sci. USA 1992, 89, 1379-1382. [CrossRef]

67. Newell, R.I.E.; Bayne, B.L. Seasonal changes in the physiology, reproductive condition and carbohydrate content of the cockle cardium (=cerastoderma) edule (bivalvia: Cardiidae). Mar. Biol. 1980, 56, 11-19. [CrossRef]

68. Kleinman, S.; Hatcher, B.G.; Scheibling, R.E.; Taylor, L.H.; Hennigar, A.W. Shell and tissue growth of juvenile sea scallops (placopecten magellanicus) in suspended and bottom culture in lunenburg bay, nova scotia. Aquaculture 1996, 142, 75-97. [CrossRef]

69. FAO (Food and Agriculture Organization of the United Nations). Fishery and Aquaculture Statistics. 2018. Available online: http://faostat.fao.org (accessed on 6 May 2020).

70. Rohatgi, A. WebPlotDigitalizer: HTML5 based Online Tool to Extract Numerical Data from Plot Images. Version 4.1. Available online: https://automeris.io/WebPlotDigitizer (accessed on 10 February 2020).

71. Toro, P.; Quijada, R.; Yazdani-Pedram, M.; Arias, J.L. Eggshell, a new bio-filler for polypropylene composites. Mater. Lett. 2007, 61, 4347-4350. [CrossRef] 
72. Lin, Z.; Zhang, Z.; Mai, K. Preparation and properties of eggshell/ß-polypropylene bio-composites. J. Appl. Polym. Sci. 2012, 125, 61-66. [CrossRef]

73. Ghabeer, T.; Dweiri, R.; Al-Khateeb, S. Thermal and mechanical characterization of polypropylene/eggshell biocomposites. J. Reinf. Plast. Compos. 2013, 32, 402-409. [CrossRef]

74. Kumar, R.; Dhaliwal, J.S.; Kapur, G.S. Mechanical properties of modified biofiller-polypropylene composites. Polym. Compos. 2014, 35, 708-714. [CrossRef]

75. Hassen, A.A.; Dizbay-Onat, M.; Bansal, D.; Bayush, T.; Vaidya, U. Utilization of chicken eggshell waste as a bio-filler for thermoplastic polymers: Thermal and mechanical characterization of polypropylene filled with naturally derived $\mathrm{CaCO}_{3}$. Polym. Polym. Compos. 2015, 23, 653-662. [CrossRef]

76. Feng, Y.; Ashok, B.; Madhukar, K.; Zhang, J.; Zhang, J.; Reddy, K.O.; Rajulu, A.V. Preparation and characterization of polypropylene carbonate bio-filler (eggshell powder) composite films. Int. J. Polym. Anal. Charact. 2014, 19, 637-647. [CrossRef]

77. Murugan, S.; Munusamy, Y.; Ismail, H. Effects of chicken eggshell filler size on the processing, mechanical and thermal properties of PVC matrix composite. Plast. Rubber Compos. 2017, 46, 42-51. [CrossRef]

78. Shuhadah, S.; Supri, A.G. LDPE-isophthalic acid modified egg shell powder composites (LDPE/ESPI). J. Phys. Sci. 2009, 20, 87-98.

79. Murugan, S.; Munusamy, Y.; Muniandy, M.; Ismail, H. Development of HDPE-modified eggshell composite. Polym. Compos. 2018, 39, 1630-1637. [CrossRef]

80. Hayeemasae, N.; Lim, W.S.; Hanafi, I. Sustainable use of eggshell powder in the composite based on recycled polystyrene and virgin polystyrene mixture. Int. J. Polym. Anal. Charact. 2019, 24, 266-275. [CrossRef]

81. Ashok, B.; Naresh, S.; Reddy, K.O.; Madhukar, K.; Cai, J.; Zhang, L.; Rajulu, A.V. Tensile and thermal properties of poly (lactic acid)/eggshell powder composite films. Int. J. Polym. Anal. Charact. 2014, 19, 245-255. [CrossRef]

82. Betancourt, N.; Cree, D. Investigation on the properties of brown eggshell powder filled poly (lactic acid) composites. In Proceedings of the 2017 Canadian International Conference on Composites (CANCOM), Ottawa, ON, Canada, 17-20 July 2017; pp. 1-8.

83. Essabir, H.; Bensalah, M.O.; Rodrigue, D.; Bouhfid, R.; El Kacem Qaiss, A. A comparison between bio-and mineral calcium carbonate on the properties of polypropylene composites. Constr. Build. Mater. 2017, 134, 549-555. [CrossRef]

84. Munusamy, Y.; Sumathi, S.; Chi, H.C. Potential use of waste cockle shell as filler for thermoplastic composite. J. Mater. Cycles Waste Manag. 2019, 21, 1063-1074. [CrossRef]

85. Ji, G.; Zhu, H.; Qi, C.; Zeng, M. Mechanism of interactions of eggshell microparticles with epoxy resins. Polym. Eng. Sci. 2009, 49, 1383-1388. [CrossRef]

86. Tiimob, B.J.; Jeelani, S.; Rangari, V.K. Eggshell reinforced biocomposite-an advanced "green" alternative structural material. J. Appl. Polym. Sci. 2016, 133, 1-10. [CrossRef]

87. Gbadeyan, O.J.; Adali, S.; Bright, G.; Sithole, B.; Awogbemi, O. Studies on the mechanical and absorption properties of achatina fulica snail and eggshells reinforced composite materials. Compos. Struct. 2020, 239, 112043. [CrossRef]

88. Azman, N.A.N.; Islam, M.R.; Parimalam, M.; Rashidi, N.M.; Mupit, M. Mechanical, structural, thermal and morphological properties of epoxy composites filled with chicken eggshell and inorganic $\mathrm{CaCO}_{3}$ particles. Polym. Bull. 2020, 77, 805-821. [CrossRef]

89. Rahman, G.S.; Aftab, H.; Islam, M.S.; Mukhlish, M.Z.B.; Ali, F. Enhanced physico-mechanical properties of polyester resin film using $\mathrm{CaCO}_{3}$ filler. Fibers Polym. 2016, 17, 59-65. [CrossRef]

90. Osman, M.A.; Ayman, A.; Ulrich, W.S. Influence of excessive filler coating on the tensile properties of LDPE-calcium carbonate composites. Polymer 2004, 45, 1177-1183. [CrossRef]

91. Osman, M.A.; Ulrich, W.S. Surface treatment of calcite with fatty acids: Structure and properties of the organic monolayer. Chem. Mater. 2002, 14, 4408-4415. [CrossRef]

92. Lin, Y.; Haibin, C.; Chi, M.C.; Jingshen, W. High impact toughness polypropylene $/ \mathrm{CaCO}_{3}$ nanocomposites and the toughening mechanism. Macromolecules 2008, 41, 9204-9213. [CrossRef]

93. Shui, M. Polymer surface modification and characterization of particulate calcium carbonate fillers. Appl. Surf. Sci. 2003, 220, 359-366. [CrossRef]

94. Liu, Z.; Gilbert, M. Structure and properties of talc-filled polypropylene: Effect of phosphate coating. J. Appl. Polym. Sci. 1996, 59, 1087-1098. [CrossRef] 
95. Tabtiang, A.; Venables, R. The performance of selected unsaturated coatings for calcium carbonate filler in polypropylene. Eur. Polym. J. 2000, 36, 137-148. [CrossRef]

96. Zoltán, D.; Pukánszky, B.; Nagy, J. Evaluation of interfacial interaction in polypropylene/surface treated $\mathrm{CaCO}_{3}$ composites. Compos. Part A Appl. Sci. Manuf. 1998, 29, 323-329. [CrossRef]

97. Guo, Z.X.; Jian, Y. Surface modification of $\mathrm{CaCO}_{3}$ with dendritic carboxylic acids. Chin. J. Polym. Sci. 2002, 20, 231-235.

98. Doufnoune, R.; Chebira, F.; Haddaoui, N. Effect of titanate coupling agent on the mechanical properties of calcium carbonate filled polypropylene. Int. J. Polym. Mater. 2003, 52, 967-984. [CrossRef]

99. Doufnoune, R.; Haddaoui, N.; Riahi, F. The Interactions of silane and zirconate coupling agents with calcium carbonate. Int. J. Polym. Mater. 2007, 56, 227-246. [CrossRef]

100. Threepopnatkul, P.; Amnard, S.; Kanpurassakorn, A.; Onanong, M.; Alongkorn, K.; Chanin, K.; Hesham, M. Preparation and properties of polylactide reinforced with eggshell modified with different fatty acids. Key Eng. Mater. 2019, 824, 16-22. [CrossRef]

101. Abdul Wahab, N.M.; Md Hanafiah, M.A.; Samsudin, D.; Mustafa, M.S.; Ahmad, Z.; Syed Ismail, S.N. Mechanical properties of silane-treated eggshell powder on unsaturated polyester composite. In Charting the Sustainable Future of ASEAN in Science and Technology; Alias, N., Yusof, R., Eds.; Springer: Singapore, 2020; pp. 435-445.

102. Shah, A.H.; Zhang, Y.; Xu, X.; Dayo, A.Q.; Li, X.; Wang, S.; Liu, W. Reinforcement of stearic acid treated egg shell particles in epoxy thermosets: Structural, thermal, and mechanical characterization. Materials 2018, 11, 1872. [CrossRef]

103. Villarreal-Lucio, D.S.; Rivera-Armenta, J.L.; Martínez-Hernández, A.L.; Estrada-Moreno, I.A. Effect of eggshell particle size in thermal and thermomechanical properties of pp/eggshell composites. Int. J. Eng. Sci. Res. Technol. 2018, 7, 82-88.

104. Supri, A.G.; Ismail, H.; Shuhadah, S. Effect of polyethylene-grafted maleic anhydride (PE-g-MAH) on properties of low density polyethylene/eggshell powder (LDPE/ESP) composites. Polym. Plast. Technol. Eng. 2010, 49, 347-353. [CrossRef]

105. Iyer, K.A.; Torkelson, J.M. Green composites of polypropylene and eggshell: Effective biofiller size reduction and dispersion by single-step processing with solid-state shear pulverization. Compos. Sci. Technol. 2014, 102, 152-160. [CrossRef]

106. Rajan, B.S.; Balaji, M.A.S.; Noorani, A.B.M.A. Effect of silane surface treatment on the physico-mechanical properties of shell powder reinforced epoxy modified phenolic friction composite. Mater. Res. Express 2019, 6, 065315. [CrossRef]

107. Ji, G.; Zhu, H.; Jiang, X.; Qi, C.; Zhang, X.M. Mechanical strengths of epoxy resin composites reinforced by calcined pearl shell powders. J. Appl. Polym. Sci. 2009, 114, 3168-3176. [CrossRef]

108. Serife, Y.; Chateigner, D.; Le Pluart, L.; Gascoin, S.; Eve, S. Investigation of structural and mechanical properties of bioCaCO $\mathrm{C}_{3}$-LDPE composites. Met. Mater. Int. 2019, 1, 29-43. [CrossRef]

109. Melo, P.M.A.; Macêdo, O.B.; Barbosa, G.P.; Ueki, M.M.; Silva, L.B. High-density polyethylene/mollusk shell-waste composites: Effects of particle size and coupling agent on morphology, mechanical and thermal properties. J. Mater. Res. Technol. 2019, 8, 1915-1925. [CrossRef]

110. Zhidan, L.; Guan, Z.; Chen, C.; Cao, L.; Wang, Y.; Gao, S.; Xu, B.; Li, W. Preparation, structures and properties of shell/polypropylene biocomposites. Thermochim. Acta 2013, 551, 149-154. [CrossRef]

111. Xian, J.; He, Z.; Li, M.; Lin, Z.; Chen, J.; Yang, Q.; Xiao, L.; Li, W. Preparation and properties of coral/ $\beta$-polypropylene biocomposites. J. Therm. Anal. Calorim. 2015, 122, 1005-1011. [CrossRef]

112. Oliveira, D.A.; Benelli, P.; Amante, E.R. A literature review on adding value to solid residues: Egg shells. J. Clean. Prod. 2013, 46, 42-47. [CrossRef]

113. Frontng, G.W.; Bergquist, D. Research note: Utilization of inedible eggshells and technical egg white using extrusion technology. Poult. Sci. 1990, 69, 2051-2053. [CrossRef]

(C) 2020 by the authors. Licensee MDPI, Basel, Switzerland. This article is an open access article distributed under the terms and conditions of the Creative Commons Attribution (CC BY) license (http://creativecommons.org/licenses/by/4.0/). 